\title{
Insulin-like growth factor-1 deficiency and metabolic syndrome
}

\author{
G. A. Aguirre', J. Rodríguez De Ita ${ }^{1}$, R. G. de la Garza ${ }^{1}$ and I. Castilla-Cortazar ${ }^{1,2^{*}}$
}

\begin{abstract}
Consistent evidence associates IGF-1 deficiency and metabolic syndrome. In this review, we will focus on the metabolic effects of IGF-1, the concept of metabolic syndrome and its clinical manifestations (impaired lipid profile, insulin resistance, increased glucose levels, obesity, and cardiovascular disease), discussing whether IGF-1 replacement therapy could be a beneficial strategy for these patients. The search plan was made in Medline for Pubmed with the following mesh terms: IGF-1 and "metabolism, carbohydrate, lipids, proteins, amino acids, metabolic syndrome, cardiovascular disease, diabetes" between the years 1963-2015. The search includes animal and human protocols. In this review we discuss the relevant actions of IGF-1 on metabolism and the implication of IGF-1 deficiency in the establishment of metabolic syndrome. Multiple studies (in vitro and in vivo) demonstrate the association between IGF-1 deficit and deregulated lipid metabolism, cardiovascular disease, diabetes, and an altered metabolic profile of diabetic patients. Based on the available data we propose IGF-1 as a key hormone in the pathophysiology of metabolic syndrome; due to its implications in the metabolism of carbohydrates and lipids. Previous data demonstrates how IGF-1 can be an effective option in the treatment of this worldwide increasing condition. It has to distinguished that the replacement therapy should be only undertaken to restore the physiological levels, never to exceed physiological ranges.
\end{abstract}

Keywords: Lipid metabolism, Insulin resistance, Dyslipidemia, Aging, Oxidative stress, GH/IGF-I axis, Obesity, Mitochondrial dysfunction, Cellular protection

\section{Background}

Consistent data from multiple studies (in vitro and in vivo) demonstrate the association between IGF-1 deficit and deregulated lipid metabolism, cardiovascular disease (CVD), diabetes, and altered metabolic profile of diabetic patients. On the other hand, metabolic syndrome (MetS) is a constellation of symptoms that implies a higher risk for CVD and type 2 diabetes (T2D), increasing the morbidity and mortality of these patients. As it is a syndrome clustering different features, the common causative aetiology is yet unknown. Nevertheless, the insulin resistance and abdominal adiposity seems to be essential in the pathophysiological process, and for this reason, based on the information available, we propose

\footnotetext{
*Correspondence: iccortazar@itesm.mx; iccortazar@gmail.com

'Escuela de Medicina, Tecnologico de Monterrey, Avenida Morones Prieto No. 3000 Pte. Col. Los Doctores, 64710 Monterrey, Nuevo León, Mexico

Full list of author information is available at the end of the article
}

IGF-1 as a key hormone in the pathophysiology of metabolic syndrome due to its implications in the metabolism of carbohydrates and lipids. Accumulated evidence shows that IGF-1 can be an effective option in the treatment of this prevalence-increasing condition, as we shall further explain in detail.

Therefore, in this review our aim is to bring all IGF-1 information regarding metabolism together with the objective of offering clear insight into the issue-this way clarifying how miss-regulation of the GH/IGF-1/insulin axis can lead to metabolic disorders such as MetS and diabetes; introducing how obesity and insulin resistance (initiating factors for the onset of MetS and diabetes) may be opposed by recombinant-human-IGF-1 (rhIGF1) treatment. Firstly, the concept of metabolic syndrome and its different definitions will be reviewed, together with the symptoms or risk factors associated. Secondly, IGF-1's molecular structure and known actions with emphasis on metabolic actions-which will be discussed 
in detail. To continue, IGF-1 and IGF-1 binding proteins will be linked to parameters of metabolic syndrome, diabetes, insulin resistance, and obesity. Lastly, IGF-1 will be proposed as valid optional treatment for patients with MetS in which diet and exercise failed due to genetic traits.

\section{Metabolic syndrome}

For many decades, the concept of "clustering" metabolic disorder and CVD risk factors has been widely discussed. Table 1 summarises historical definitions and evolution of MetS diagnosis. However, the term "Metabolic Syndrome" has become commonly used since its inception by the "Executive Summary of the Third Report of the National Cholesterol Education Program" (NCEP) in 2001 [1]. Since then, many different concepts and definitions have been proposed. Hence, it was not until 2009 when a harmonised definition was finally described [2]. According to this definition, a diagnosis of MetS is made when 3 of the following 5 risk factors are present: enlarged waist circumference with population and country-specific criteria; elevated triglycerides (defined as $\geq 150 \mathrm{mg} / \mathrm{dL}$ ), decreased High Density Lipoprotein (HDL) (ranges below $40 \mathrm{mg} / \mathrm{dL}$ in men and $50 \mathrm{mg} /$ $\mathrm{dL}$ in women), elevated blood pressure (defined as systolic blood pressure above $130 \mathrm{mmHg}$ or diastolic blood pressure above $85 \mathrm{mmHg}$ ) and elevated fasting glucose (defined as blood glucose above $100 \mathrm{mg} / \mathrm{dL}$ ). This definition includes those patients that are taking medication to manage hypertriglyceridemia, low HDL, hypertension and hyperglycemia [2].

In general MetS continues to be a clustering of symptoms that seem to play a major role as CVD and T2D risk factors, raising the necessity of encouraging these patients to pursue lifestyle changes. Moreover, the harmonised definition criteria was found to be a better predictor of CVD than each of its separate components or the Framinghan Score-this was not applicable for T2D [3].

The prevalence of MetS is difficult to establish since it depends on the definition $[1,2,4-6]$ and the composition of the population being studied [7-29]. To dissolve this issue different studies have been undertaken in order to estimate the prevalence of MetS. Nowadays we can understand that sex, age, race and ethnicity, in the context of socioeconomic status and lifestyle (tobacco, alcohol, education, physical exercise, unbalanced diet, etc.) impacts directly in its prevalence [7, 8, 10, 27-36]. Furthermore, it is well known that it is increasing worldwide [37], this is thought to be related to the westernisation of lifestyle habits [38, 39].

It is well known that MetS represents an assortment of factors that increase the risk of CVD [11] and T2D by different means [11, 40-55]. Obesity and insulin resistance are associated with endothelial dysfunction, sympathetic nervous system hyperactivity, and hyperleptinaemia, all of which can lead to hypertension. Furthermore, insulin resistance can lead to abnormal lipid profiles, like low-HDL and high triglyceride (TG) levels. These two factors can increase the risk for CVD [56-60], nonetheless there is some controversy about the role of TG levels in the CVD development [57]. In summary, the majority of the studies have found that patients with MetS are at increased risk for developing CVD [11, 37, 39-55]. Additionally, as previously mentioned, a recent study has described that MetS -taking the harmonised definition criteria for diagnosis-is a better predictor for CVD than the sum of each of its separate components or the Framingham Score. Other studies have found that the more components of the MetS are present, the greater the risk of developing CVD [42, 53, 61].

Moreover, MetS is also a good predictor for the development of T2D [62-64]. Insulin resistance, hyperinsulinemia, dyslipidaemia, and obesity precede the progression to T2D in $75-85 \%$ of patients [65], and the presence of MetS increases up to fivefold the risk for T2D compared to individuals without MetS [66, 67]. This risk is increased up to 6-7-fold, if insulin resistance is present [54].

Other conditions that have been associated with MetS are strongly related with insulin resistance and adiposity, namely, non-alcoholic fatty liver disease (NAFLD), polycystic ovarian syndrome, obstructive sleep apnoea (OSA), hypogonadism, lipodystrophy, and microvascular disease. Moreover, the presence of NAFLD is a robust predictor of MetS [68]. Liver fat also correlates to each of the components of MetS [69]. In the case of OSA, there is evidence-adjusting for obesity-that individuals with this alteration are more likely to develop MetS than those without OSA [70-72]. Also, sleep disorders have been associated with weight gain and insulin resistance [73-77]. In the case of microvascular disease, some studies relate it to MetS, independent to the presence of T2D [78-86], but further studies are needed to ensure these results.

\section{Insulin-like growth factor-1}

Insulin-like growth factor 1 (IGF-1) is a 70-aminoacid polypeptide hormone with endocrine, paracrine, and autocrine effects, which shares structural homology ( $>60 \%$ ) with IGF-2 and proinsulin [87, 88]. It is mainly produced by the liver (accounting for $\approx 75 \%$ of circulating IGF-1) secondary to growth hormone $(\mathrm{GH})$ and insulin endocrine stimulation in the liver. Conversely, IGF-1 acts to provide an inhibitory feedback signal on $\mathrm{GH}$ secretion in the hypothalamus by stimulating 


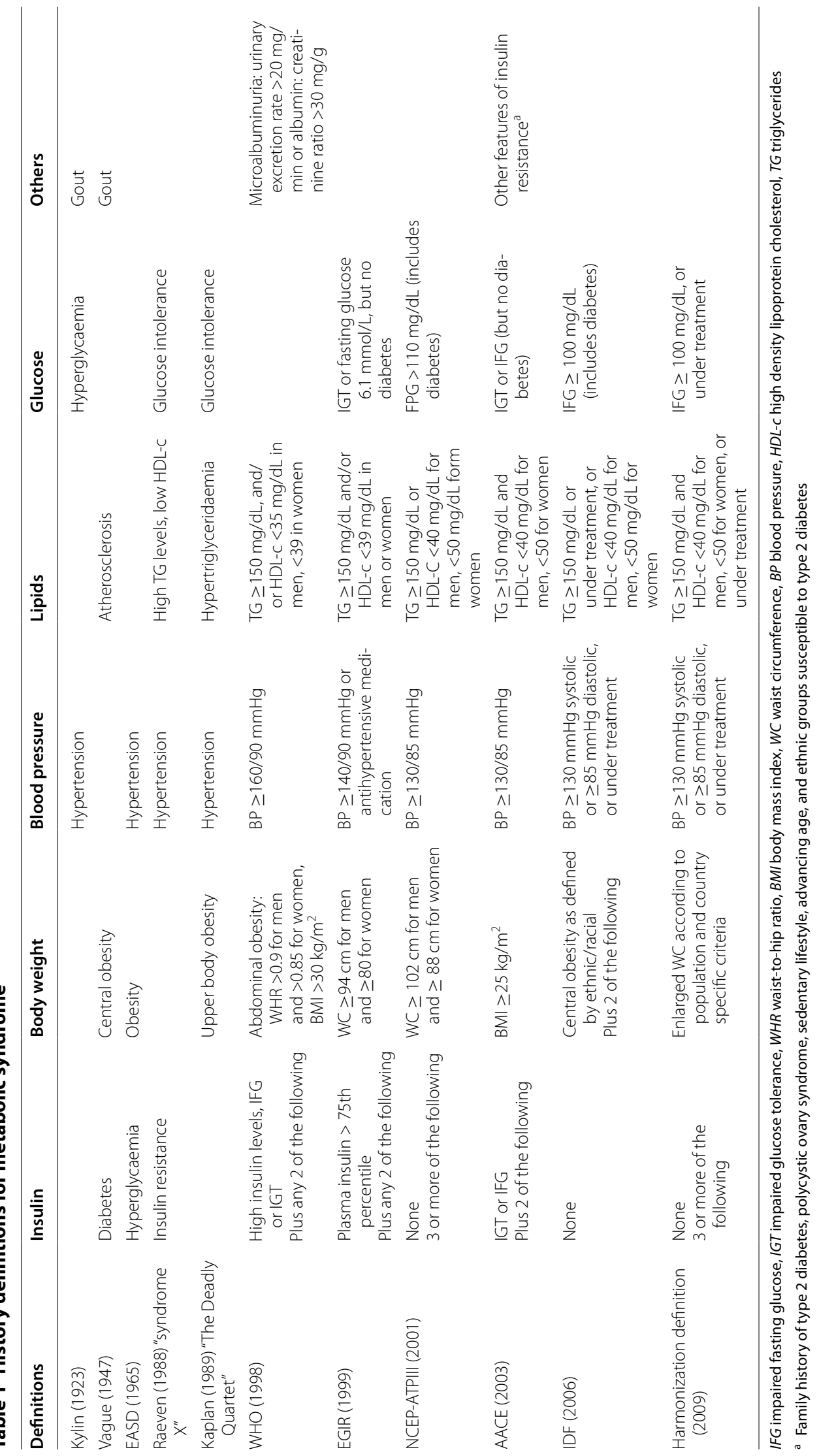


somatostatin production in the pituitary [89-91]. IGF-1 is also produced locally in all bodily tissues [92]. IGF-1 availability is tightly regulated by the so-called insulinlike growth factor binding proteins (IGFBPs), which may act by increasing IGF-1 half-life, from minutes to hours (most commonly by forming a tertiary complex with Acid-Labile Subunit and IGFBP3), however blocking its binding to the insulin-like growth factor 1 receptor (IGF1R) [93-95]. IGFBPs can also act to guide IGF-1 to specific tissues, or even to inhibit or potentiate IGF-1 actions by acting as an independent substrate for the IGF-1R and/or other specific membrane, intracellular or nuclear receptors [93-95]. To date there have been described 6 high affinity IGFBPs [93-95]. Moreover, insulin-like growth factor binding protein related proteins (IGFBPrPs) have been recently characterised, which aid the metabolic effects of the hormone but their role remains unclear [96, 97]. Relevant roles of each specific IGFBPs will be further discussed when applicable to metabolism since there is a huge emerging world of IGFBPs independent actions.

IGF-1 can act over its putative receptor (IGF-1R) or it can also bind to the insulin receptor (IR), albeit with less affinity [98-100]. In addition, there is a hybrid receptor with components of the IR (one $\alpha$ and one $\beta$-chain) and the IGF-1R (one $\alpha$ and one $\beta$-chain), to which both insulin and IGF-1 can bind to, but with less affinity than that of their putative receptors [98-100]. All of these receptors have tyrosine kinase activity, hence are natural and potent activators of the Akt pathway [98-100].

IGF- 2 actions have been poorly characterised, however relevant roles have been determined for foetus development and cerebral protection [101, 102]. IGF-2 can act over its own receptor (IGF-2 receptor-IGF-2R), which is a manose-6-phosphate transmembrane protein with undetermined actions-it is thought that it acts as a scavenger receptor by sequestering IGF-2 and IGF-1 from the extracellular medium and targeting them for destruction [103]. Nonetheless, it seems that it could have intracellular targets instead of only being proteolysed. As of recent discovery IGF-2R shows to activate $G_{\alpha q}$ proteins within cardiomyocites [104]. Additionally, IGF-2 can also act over IGF-1R, IR and hybrid receptors but with reduced affinity [103].

In the last decades, IGF-1 has been implicated in many physiological actions, among others: tissue growth and development, proliferative, lipid metabolism, pro-sur$\mathrm{vival}$ /anti-aging, anti-inflammatory, anabolic, and antioxidant with neuro- and hepatoprotective properties [105-116]. IGF-1 exerts protective effects over mitochondria by preserving it from the oxidative damage generated by augmented metabolism, and increasing ATP synthesis and reducing intramitochondrial production of free radicals [105-107].

\section{Insulin receptor, insulin-like growth factor-1 receptor and insulin resistance signalling}

As a brief review of insulin signalling and its resistance molecular basis: insulin and IGF-1 receptors (IR and IGF-1R) are tyrosine kinases. As such they attract molecules containing a Src-homolgy 2 (SH2) domain (several docking sites for phosphorylated tyrosines). The most often and potent ones attracted are the insulin receptor substrates $1 / 2$ (IRS1/2) - although there are 6 found to date- (not to forget that Shc proteins, p60dok, Cbl, APS, and Gab-1 are also recruited to activated IRs). These provide additional tyrosine residues to be phosphorylated by the tyrosine kinase domain of the activated receptor that will attract further molecules containing $\mathrm{SH} 2$ domains or plekstrin homoly $(\mathrm{PH})$ domains, these last will anchor IRS to phosphoinositides on the cell membrane. When PI3K and its regulatory proteins, p 85 and p110, are recruited by IRS, they will further recruit and activate PDK1 ( $\mathrm{PIP}_{3}$-dependent kinase 1), Akt (PKB), mTORC2, S6 kinases and PKC; all leading to augmented glucose transport, glycogen and protein synthesis. Zick and colleagues [117] have elegantly summarised recent evidence that show how IRS also possess serine residues that can be phosphorylated. When this happens tyrosine phosphorylation becomes less likely to happen. This is, in a certain way, a termination pathway to uncouple the insulin signalling. There are other mechanisms to terminate the insulin signalling that include lipid and protein phosphatases along the cascade and controlling mechanisms; long-term regulation includes transcription inhibition of the IR and proteolysis by ubiquitination. One convergent pathway activated by IGF-1R and IR is the mTORC1 and mTORC2 signalling. It is widely known they both posses serine and threonine phosphorylation capability. However, it has been recently described that mTORC2 also possesses tyrosine phosphorylation capacity [118], and that it phosphorylates tyrosines on IRS and tyrosine kinases in both receptors, IGF-1 and IR, thus reinstituting the signal of the activated receptors [118]. Whilst mTORC1 activates $\mathrm{S} 6$ kinase, which phosphorylates serine residues on IRS which in turn uncouples IRS from the receptor and its substrates, mTORC2 can reactivate this signalling.

Complementary to the above, it has been thought for a long time that only supraphysiological concentrations of IGF-1 are able to activate the IR, as will be further discussed in this manuscript. However, the exact mechanism by which IGF-1 improves insulin signalling has not yet be explained (other than indirect actions through 
lipid clearance from the bloodstream by inhibiting GH (lipolysis on adipocytes) and FFA uptake by muscles; all these mechanisms are collected below). We now propose a feasible mechanism: Denley and colleagues [119] have beautifully designed a study where they demonstrate how IR has a splice variant lacking exon 11 which confers the receptor affinity for IGF-1 and IGF-2. In this way, IGF-1 gains the ability to stimulate the IR, and without activating the tyrosine kinase domain, recruits IRS-2. Complementarily, IGF-1R preferentially activates IRS-2 [120] as it was found that IRS-2 contains a KLRB domain that functions to block the tyrosine kinase domain in the cytoplasmic region of the IR, and that such does not happen in the IGF-1R. Thus suggesting a specificity for IGF-1R. It has been found, using specific knock out (KO) mice and cultures, different specific activities for IRS-1 and IRS-2, additional further complexity comes with tissue-specific roles. For example, in muscle, IRS-1 is more related to glucose uptake whereas IRS-2 stimulates the MAPK pathway [121]. In the liver, they both have metabolic regulation actions, but IRS-2 has a more profound role in lipid metabolism [121]. Additional complexity, and in accordance with IGF-1 secretion patterns, appeared when researchers found that IRS-1 was found more active in post-prandial states contrary to IRS-2 in fasting states [121]. Even more interesting is the fact that Shc and PLC were found to only interact with IRS-2 [121]. Recall that Shc ultimately activates the MAPK pathway, while PLC has more metabolic effects including GLUT4 translocation. IGF-1 displays more binding sites for SHP2 (a phosphatase related to growth) and seems more prone to recruit $\mathrm{Cbl}$ [121] (an E3 ligase that targets the receptor for ubiquitination and destruction) and thus may explain a different regulatory mechanism not mediated by serine phosphorylation, and thus not so sensitive to metabolic derangements. Intriguingly, another interesting research lead to the discovery of a differential role for IRSs in apoptosis, suggesting an antiapoptotic effect for IRS-2 [122] which is consistent with known differential roles of IGF-1 and insulin.

Taking all this data together it seems logical or appropriate to conclude that, because IGF1-R has a different signalling pathway that can maintain lipid oxidation in the liver, FFA uptake in muscle, and activates mTORC1 could reactivate IR through tyrosine kinase activity on IRS, thus displacing serine phosphorylation, reinstituting insulin signalling. Also since most of serine inhibiting phosphorylation occurs in IRS-1, it renders IGF-1R a rescue pathway to reinstitute insulin sensitivity. Because IGF-1 is normally found at low levels in MetS and T2D, maybe because of insulin cessation to inhibit IGFBP-1 production by the liver and because of decreased liver IGF-1 secretion by insulin stimulation, as insulin resistance prevails in the liver. Consistent with the evidence presented we suggest a positive effect towards reestablishing IGF-1 levels by substitutive therapy only to physiological levels, never above them.

\section{Insulin-like growth factor-1 metabolic effects}

At a first glance, IGF-1 has historical fame for being a growth and differentiation factor, however, a number of growth-unrelated actions have been recently unravelled [123]. From our perspective IGF-1, GH, and insulin conform a finely regulated axis that inform cells about the nutritional status of the organism so that they can either undergo apoptosis/senescence/quiescence or, to the contrary, grow and differentiate. Parallel to this signal, potent protective effects have been attributed to this hormone, thus, besides signalling abundance and growth, it provides the protection against the possible deleterious effects of augmented metabolism. Likewise, antiinflammatory actions of IGF-1 [124] can be regarded as a crucial factor protecting tissues from the deleterious effects of pro-inflammatory mediators in chronic disorders such as obesity. It has been well established that pro-inflammatory cytokines produced by the adipose tissue in obesity affect normal nutrition-related signalling, establishing the progression to MetS and ultimately to T2D [125]. Additionally, it is now known that proinflammatory cytokines also hijack IGF-1 intracellular signalling by phosphorylating serine residues on insulin related substrate (IRS) molecules and hence impeding their binding to IGF-1R [124]. This results in a blockade of IGF-1 beneficial actions [124, 126, 127]. Under this scenario, a correlation between IGF-1 and MetS can be established.

When caloric restriction is present, mammals synthesise less IGF-1 and its synthesis in the liver is refractory to GH stimulation [128-130]. This process functions to limit growth and protein synthesis when nutrient availability is compromised. After a meal, GH responsiveness and IGF-1 synthesis is reinstituted $[105,106]$. When inadequate carbohydrates are ingested, the decrease in portal vein insulin concentration leads to a reduction in IGF-1 synthesis by the liver $[129,131]$. In pathophysiological states, including increased insulin resistance, the hybrid receptor number is changed significantly, thus potentially abrogating the chance for IGF-1 to alter glucose metabolism [129, 132, 133]. It is important to mentions that IGF-1 receptors are expressed ubiquitously [99]. This means that their actions can occur in all cell types, stimulating fat, carbohydrate, and protein metabolic coordination, as we shall explain in detail herein. IGF-1 possesses both, GH-like actions and insulin-like actions, whose effects in vivo depend on the dosage, length of treatment, and even route of administration 
[134, 135]. However, GH can also exert metabolic actions independent from IGF-1 generation in the liver via activation of the phosphoinositide 3-kinase (PI3 K) and IRS pathways [98]. In this way, GH and insulin act in symphony with IGF-1 to produce a coordinated response. Supported by an increasing number of studies these effects suggest the involvement of IGF-1 in metabolism coordination [136].

\section{Insulin-like growth factor-1 and carbohydrate metabolism}

IGF-1 can promote glucose uptake in certain peripheral tissues [137-140] in the magnitude of 4-7 \% from that of insulin [141, 142]. In addition, exogenous IGF-1 administration has been shown to reduce serum glucose levels $[95,143,144]$, not only in healthy individuals $[140,145-$ 147], but also in those with insulin resistance [148, 149], type I [150-152], and T2D [153-155]. An interesting experiment shows how, in the presence of insulin resistance, there is up-regulation of the insulin/IGF-1 hybrid receptor expression in both, muscle and fat $[133,156]$. It is important to bear in mind that IGF-1 serum concentration is 100 -fold greater than insulin, however when bound to IGFBPs its biological activity is modulated and in its free-unbound form presents different effects [99, 157]. High doses of IGF-1 administration typically results in hypoglycaemia despite the potent suppression of circulating insulin concentrations it triggers $[134,135,158]$. Even though this effect may be mediated by the insulin receptor, experimental $\mathrm{KO}$ mice for the insulin receptor gene show a potent glucose lowering effect of IGF-1, indicative that the hypoglycaemic effect is also mediated, in part, by its own IGF-1R. However, this study was undertaken in 1-3 day old mice, as without IR they were not viable, and thus, results are not conclusive [159].

Berryman and colleagues revised IGF-1 actions on obesity, and concluded that this molecule possesses direct effects on muscle glucose uptake [160]. Moreover, KO mice for liver IGF-1 gene developed muscle insulin resistance (it is important to mention that skeletal muscle myocytes express high number of IGF-1R), showing an increase in insulin concentrations and a substantial decrease in the insulin-induced autophosphorylation of the insulin receptor and IRS in skeletal muscle (being normal in liver and white adipose tissue). This effect was efficiently reverted by IGF-1 administration [161]. Such results could indicate that hepatic derived IGF-1 plays a crucial role in skeletal muscle insulin signalling and glucose uptake. In murine studies, deletion of the IGF-1R in skeletal muscle resulted in glucose intolerance issues ultimately leading to T2D at an early age, because, although they express insulin receptors, they cannot form hybrid or IGF-1 receptors [162]. When these mice where administered IGF-1 they showed lowered fasting glucose, and because no functional IGF-1R is present in muscle, such effect is believed to be due to renal gluconeogenesis suppression [129, 163]. Our group, working with partially deficient IGF-1 mice, has demonstrated that the liver is capable of expressing IGF-1R (which under physiological conditions it does not [99]) as a "defence" mechanism (peer review). If the abovementioned is occurring, it could mean that IGF-1 administration could also lower glucose levels by suppressing hepatic gluconeogenesis, as well as improving insulin signalling in this organ, leading to IGFBP-1 suppression and overall improvement of the IGF-1/GH/insulin axis. Furthermore, additional performed studies suggested [164] that genetic expression of enzymes involved in glucose and lipid homeostasis together with cholesterol transport are altered (as we shall further explain in detail later on).

IGF-1 reduces serum GH levels (via somatostatin negative feedback in the pituitary) which in turn suppresses $\mathrm{GH}$ actions in the liver, thus enhancing insulin actions in this organ [165]. In both, fat and liver, GH stimulates the synthesis of p85 subunit of PI3K [166] leading to the suppression of p110 subunit activity and, thus, antagonising insulin's actions [167]. Therefore, IGF-1 may indirectly modulate carbohydrate metabolism through GH suppression and enhancement of insulin action.

During postprandial periods there is an increase in free circulating IGF-1 via insulin-induced suppression of IGFBP-1 secretion [168-170], which sequesters free IGF-1 making it unavailable. IGFBP-1 gene is transcriptionally regulated by insulin in the liver [169]. This change in available IGF-1 may be (it is difficult to extrapolate data from altered IGF-1/GH concentrations from animal models, as each author measures IGF-1 levels using different methods) adequate for fatty acid (FA) oxidation in muscle, suppression of GH, stimulation of glucose transport into muscle [171, 172], and lastly for the suppression of renal gluconeogenesis in mice [163].

Besides the already discussed actions of IGF-1 on glucose, it also has an indirect glucose-lowering effect secondary to its ability in increasing FA oxidation in muscle (will be further discussed in detail within the IGF-1 and lipid metabolism section). Such ability produces a decreased FFA flux in the liver and hence insulin signalling is improved, being now able, such signalling to suppress hepatic glucose output [166].

IGFBPs are also hypothesised to play a role in glucose metabolism. IGFBP-1 regulates glucose levels through its effect on free IGF-1. IGFBP-2 actions are linked to insulin, although only in cases of hyperinsulinemia [173] where it seems to play a role on adipocyte autocrine control [174]. It has been reported that IGFBP-3 binds to a nuclear receptor, 9-cis retinoic acid receptor-alpha (RXR$\alpha$ ), which interacts with peroxisome proliferator activated 
receptor-gamma (PPAR- $\gamma$ ), a nuclear protein involved in the regulation of glucose and lipid metabolism $[175,176]$. A transgenic mice study stated that the overexpression of IGFBP-3 is associated with impaired glucose tolerance $[177,178]$. Also, IGFBPrPs have been associated with insulin resistance and fasting glucose levels [179, 180].

In a recent investigation undertaken by our group, adult mice with partial IGF-1 showed a decrease in the expression of genes involved in glucose metabolism (phosphoenolpyruvate carboxylase-1, glucose-6-phosphatase, pyruvate dehydrogenase kinase isoenzyme-4, and ATP-citrate lyase), resulting serious hyperglycaemia [164]. Such genetic alterations were all reverted by low doses if IGF-1 replacement therapy for only 10 days. Interestingly, it is well accepted that insulin increases the expression of glucose-6-phosphatase and phosphoenolpyruvate carboxylase- 1 . Results in the study demonstrate that IGF-1 induces the opposite effects since the IGF-1 deficit reduces the expression of glucose-6-phosphatase and phosphoenolpyruvate carboxylase-1. Thus, these activities of IGF-1 are not "insulin-like" but rather antagonistic. These findings reinforce the role of IGF-1 in glucose homeostasis. Also, pyruvate dehydrogenase kinase isoenzyme-4 encodes pyruvate dehydrogenase complex (PDK). PDK is an emerging target for the treatment of MetS which may allow the maintenance of the steady-state concentration of adenosine triphosphate during the feed-fast cycle. For that, cells require efficient utilization of fatty acids and glucose, and such is controlled by PDK. Particularly the pyruvate dehydrogenase kinase isoenzyme-4 gene encodes PDK that converts pyruvate, CoA and oxidized nicotinamide adenine dinucleotide (NAD+) into acetyl-CoA, the reduced form of nicotinamide adenine dinucleotide (NADH) and carbon dioxide.

\section{Insulin-like growth factor-1 and lipid metabolism}

IGF-1 promotes preadipocyte differentiation [181], however, as preadipocytes differentiate, they stop expressing IGF-1Rs, delegating such functions now to insulin receptors, which increase in number significantly. Thus, in the adipose tissue, physiological IGF-1 concentrations are not effective in stimulating changes in lipid synthesis or lipolysis, only at high concentrations is capable of stimulating glucose transport via the insulin receptor [182]. Contrarily, a study with $8 \mathrm{GH}$-deficient subjects found that IGF-1 administration increased lipid oxidation (being this effect more potent when co-administered with $\mathrm{GH}$ ), energy expenditure, and insulin resistance $[108,183]$. This effect is believed to be due to IGF-1 suppression of insulin secretion, which leads to augmented lipolysis in adipose tissue and promotion of FFA use by muscle.
Although mature adipocytes are not a target for IGF-1, they secrete it. In fact, cultured adipocytes secrete more IGF-2 than IGF-1, and predominantly IGFBP-4. Growth hormone, interleukin- $\beta$ (IL-1 $\beta$ ), and TNF- $\alpha$ affect secretion of IGF-1-whereas IGF-2 is affected by TNF- $\alpha$ only. Hence, cytokines may control adipocytes homeostasis by affecting local IGF-1 synthesis [160].

Growth hormone has direct effects on mature adipocytes that result in the release of FFAs following TG breakdown and in increased FFA oxidation in the liver [182]. GH can enhance the lipolytic effect of catecholamines by increasing the number of adrenergic receptors in adipocytes. GH also increases hepatic glucose production $[184,185]$ and leads to increased lipolysis in adipocytes through the $\beta-3$ adrenergic receptor $[185,186]$. Such receptor activates the protein kinase A (PKA) cascade, eventually activating lipases $[185,187,188]$. Additional effects include uncoupling of the electron transport chain to produce heat $[185,189]$. In skeletal muscle, GH increases lipoprotein lipase activity via the $\beta$-3 adrenergic receptor, as a result facilitating FFA use [186].

On the other hand, insulin is a potent stimulant of lipid synthesis, antagonising TG breakdown. An increase in FFA efflux from adipose tissue to liver can result in insulin resistance in the liver and GH is known to antagonise insulin action by this mean [183]. Definitive evidence of the role of FFAs in GH-mediated insulin resistance was obtained in clinical studies in which the effects of exogenously administered GH on insulin resistance were abrogated by Acipimox ${ }^{\text {TM }}$-an inhibitor of lipolysis [185, 190, 191]. The increased efflux of FFAs from adipose tissue to lipid-sensitive tissues (such as liver and skeletal and cardiac muscle) increases serine phosphorylation of IRSs. Such phosphorylation leads to the blockade of the tyrosine residues in IRSs, to which the insulin and IGF-1 receptors phosphorylate to activate IRSs and consequently commence the signalling cascade $[185,192]$, as comprehensively discussed above.

IGF-1 promotes fatty acid transport in muscle [162, 183, 193] and its inhibition causes severe consequences like insulin resistance and eventual diabetes [162]. This is due to the liver taking up all the circulating FFAs, which then interfere with insulin and IGF-1 signalling (as described above) and eventually leading to hepatic steatosis. Therefore, the two major effects that are enhanced by IGF-1 are FFA use by muscle and GH suppression. These two actions result in a decreased FFA flux in the liver, improving insulin and IGF-1 signalling. Such improvement promotes lipogenesis in fat (recall that IGF-1 could maintain cytokine homeostasis-antiinflammatory effects-, and thus protection from mild inflammation as a consequence of obesity). This fact, linked to the augmented FFA use by muscle and insulin 
signal reinstitution by IGF-1, results in a marked reduction in total FFA flux.

Moreover, IGF-1 could be implicated in nutrient absorption as our group demonstrated more than a decade ago. We showed that cirrhotic (an IGF-1 deficiency condition) rats had diminished amino acid and glucose intestinal absorption [114, 194, 195] and that IGF-1 replacement therapy was able to restore both alterations, suggesting a role of IGF-1 in the position of transporters [196]. Such findings suggest that IGF-1 implications on metabolism may not only affect energy use and balance, but as well act regulating transport and nutrient absorption. Therefore, this finding could be indicating that IGF-1 deficiency could be altering nutritional balance. However, more profound studies in the matter are necessary.

In the aforementioned study from our group, adult mice with partial IGF-1 also displayed decreased expression of genes involved in lipid metabolism (ATP-citrate lyase, acetyl-CoA acyltransferase $1 \mathrm{~B}$, acetyl-CoA acetyltransferase 1) and cholesterol synthesis and transport (Both HMG-CoA reductase and synthase, LDL-related protein 1, proprotein convertase subtilisin/Kesin type 9), resulting in dyslipidaemia. Such genetic alterations were reverted by IGF-1 replacement therapy and may seriously contribute to the establishment of MetS [164].

Figure 1 and Table 2 have been included to represent schematically IGF-1 actions in metabolism with target organs.

\section{Can insulin-like growth factor-1 deficiency be involved in metabolic syndrome establishment?}

An assortment of epidemiological and clinical studies have stated glucose and lipid metabolism alterations, insulin resistance, and central obesity as predominant factors for the development of MetS [38, 212].

Similarities between insulin and IGF-1 suggest the possible role of IGF-1 in the pathological process of this syndrome, therefore several studies have attempted to correlate IGF-1 plasma levels with MetS. Figure 2 represents the pathophysiology of an altered IGF-1/GH/insulin axis, and potential beneficial actions of IGF-1 therapy.

A general finding is that obese patients fulfilling criteria for MetS together with low IGF-1 plasma levels tend to develop a worse cardiovascular disease outcome than those with mid-normal to high-normal IGF-1 levels [213]. Nevertheless, many of them also present insulin resistance and inflammatory cytokine secretion, so it is difficult to determine the exact role of each component in the cardiovascular outcome.

Nonetheless, low IGF-1 circulating levels are also associated with reduced insulin sensitivity [207], glucose intolerance, and T2D [207, 208, 214]. Moreover, some inflammatory cytokines are known to reduce IGF-1 levels in animal models [215]. Additionally, the IGF-1/IGFBP-3 ratio, a common rough of free IGF-1 levels, is significantly decreased in obesity [216], however no IGF-1 bioactivity was estimated. This parameter has been further studied, showing that those men and women in the lowest quartile of the IGF-1/IGFBP3 ratio are threefold more likely to meet the Adult Treatment Panel III (ATPIII) definition for MetS, and twice as likely to be insulin resistant-that IGF-1/IGFBP-3 ratio decreases notably as the number of MetS components increases [217]. Furthermore, visceral adipose tissue mass has been inversely correlated with circulating IGF-1 levels [216]. Nevertheless, the mechanism of this possible inverse relationship between MetS and free IGF-1 levels remains unclear.

A very interesting epidemiological study that supports this idea showed that in normal subjects, IGF-1 contributes to glucose homeostasis. This study analysed a group of Dutch Caucasians with a polymorphism in the promoter of the IGF-1 gene $[129,218]$. Results within this group showed a reduced IGF-1 secretion-40 \% lower than those without the polymorphism. These subjects are $2.1 \mathrm{~cm}$ shorter and have 2.2-fold increase in T2D prevalence after the age of 60 [129, 219]. A different study [220] tested IGF-1 in response to energy intake in the Gujarati migrant community in Sandwell (UK) and data was compared with people still resident in their village of origin in India. Total energy and total fat intake were higher in UK migrants, as were IGFBP-3 and IGF-1, but IGFBP-1 was lower in UK migrants. At both sites, IGF-1 and IGFBP-3 correlated positively with total energy and fat. Conversely, in Indian Gujaratis, IGFBP-1 fell with increasing total energy and fat intake but not in UK Gujaratis.

Several other studies (one of them being a large scale community-based Framingham Heart Study [221]) have suggested a role for IGF-1 in the prevalence of insulin resistance and MetS [221-223]. Biomarkers correlating the lower IGF-1 concentration to increased waist-to-hip ratio or to impaired glucose tolerance are also being studied [224, 225].

Insulin-like growth factor-1, as discussed earlier, has implications on lipid and glucose metabolism [87, 88], and its exogenous administration enhances insulin sensitivity in healthy adults $[139,140]$ as well as those with T2D [155].

A fascinating study including over 500 patients revealed that IGF-1 concentrations were independently associated with insulin sensitivity accounting for $10.8 \%$ of its variation. The results were assessed by HOMA$S$ together with anthropometric measurements, HDL, TG and blood pressure, and found correlations between these parameters and IGF-1 plasma levels. Additionally, they established that according to the WHO definition 


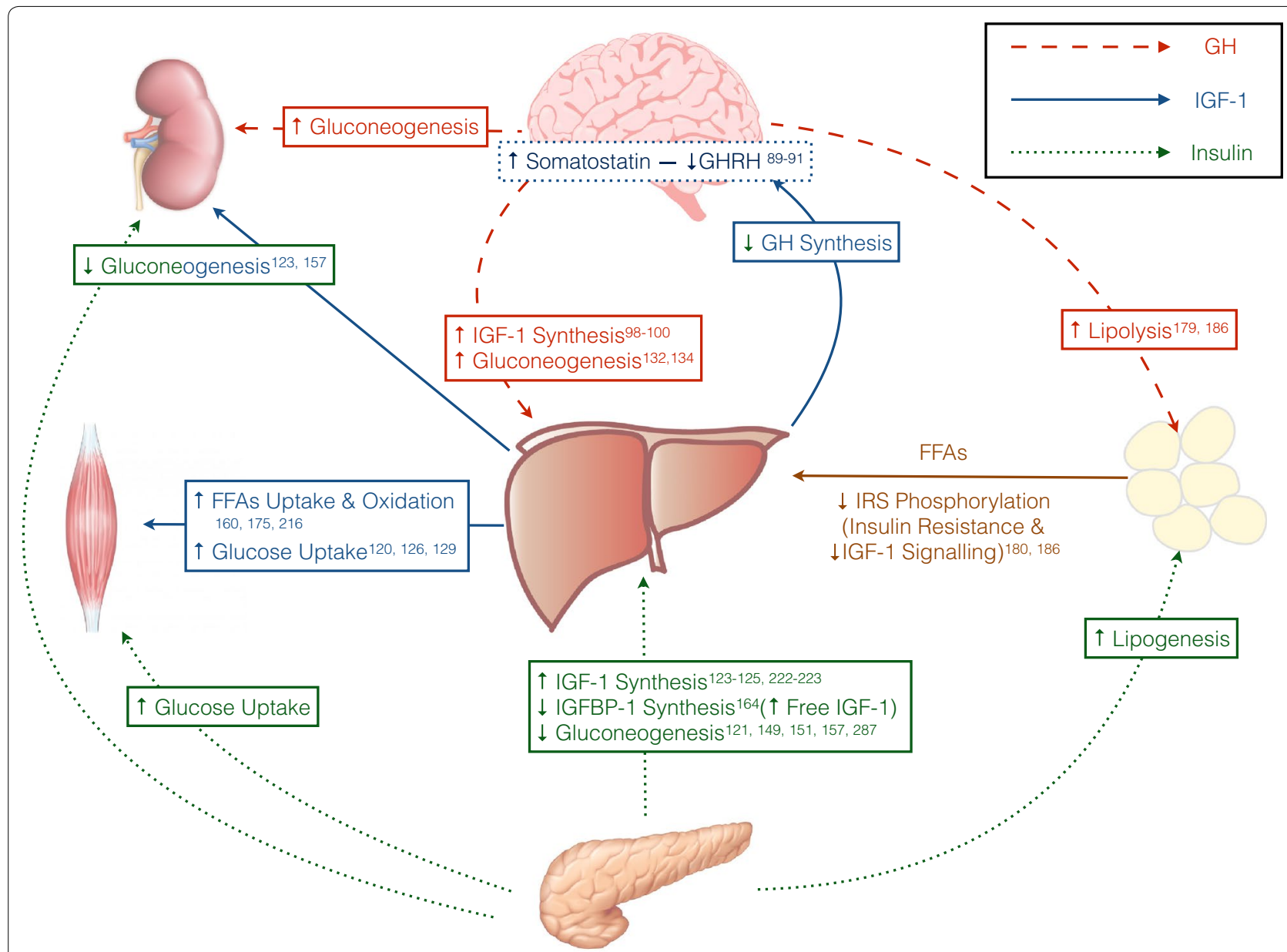

Fig. 1 Metabolic effects of IGF-1, GH, and insulin under physiological conditions on their target organs. The figure summarises schematically some of the metabolic effects that IGF-1 (blue continuous line), GH (red discontinuous line), and insulin (green dotted line) exert on kidney (upper left), brain (upper centre), skeletal muscle (left), liver (centre), adipose tissue (right), and pancreas (bottom). GH growth hormone, GHRH growth hormone releasing hormone, FFA free fatty acid, IRS insulin receptor substrate, IGF-1 insulin-like growth factor 1, IGBBP-1 insulin-like growth factor binding protein 1

for MetS, each unit increase in log-transformed IGF-1 concentrations, was associated with a $90.5 \%$ reduction in the risk of MetS [226].

Salmon et al. [227] showed that transgenic mice with reduced levels of IGF-1 can induce female insulin resistance [227]. Moreover, global deletion of IGF-1 gene expression in mice does not result in glucose intolerance. It has to be mentioned that KO mice for IGF-1 gene are not viable and studies in such mice have to be done in the first days of life, and thus results are not very conclusive as metabolism is not properly established at this stage $[129,228]$. However, if a partial deletion is present, the mice will develop glucose intolerance if starved. Additional studies found that elimination of hepatic IGF-1 gene expression results in a compensatory threefold increase in $\mathrm{GH}$ secretion-recall that IGF-1 is secreted by $\mathrm{GH}$ stimulation in hepatocytes. This combination of lowered serum IGF-1 and increased GH secretion leads to increased insulin resistance-as in the systemic deletion but also developed glucose intolerance [129, 209]. Interestingly, glucose intolerance could be improved when IGF-1 was systemically administered. This response was caused primarily by GH hypersecretion, as expression of a GH antagonist resulted in improvement of glucose homeostasis [129, 229]. Additionally, administration of IGF-1 in the presence of this antagonist results in a further improvement in insulin sensitivity; suggesting that, at high concentrations, IGF-1 has effects not simply mediated by suppressing the effect of $\mathrm{GH}$ on hepatic insulin sensitivity $[129,209]$. In a similar study, the pivotal role for the IGF-1 in insulin sensitivity has received further support from liver-specific IGF-1 KO mice which exhibited overt insulin resistance and hyperinsulinaemia that was reversed by the administration of IGF-1 [161]. 


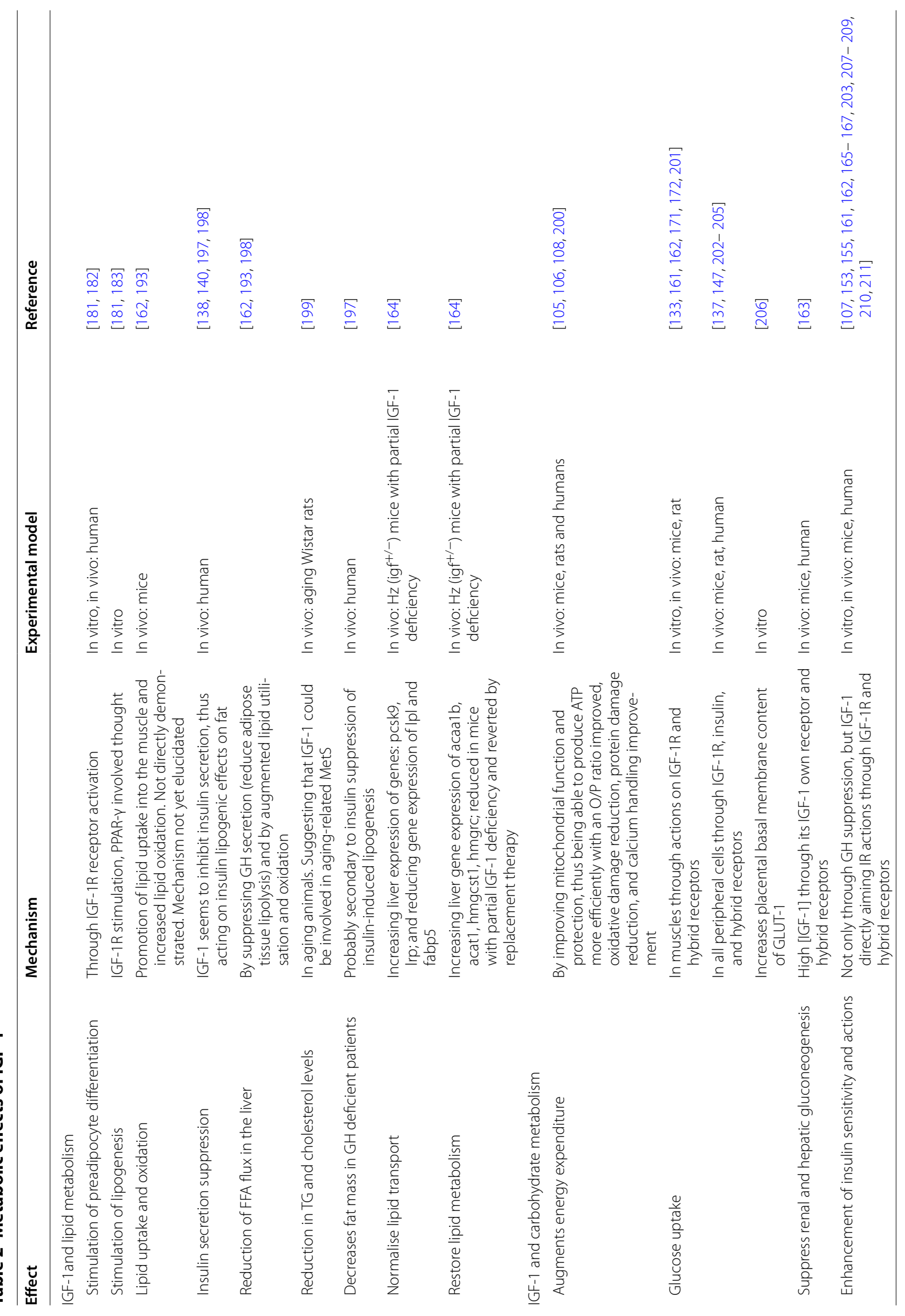




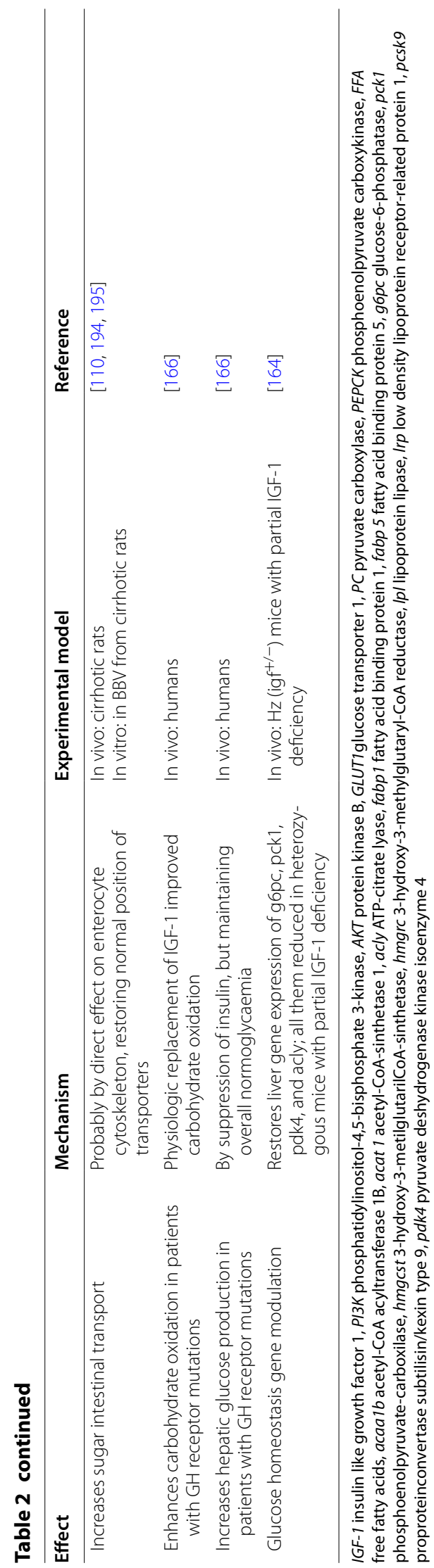




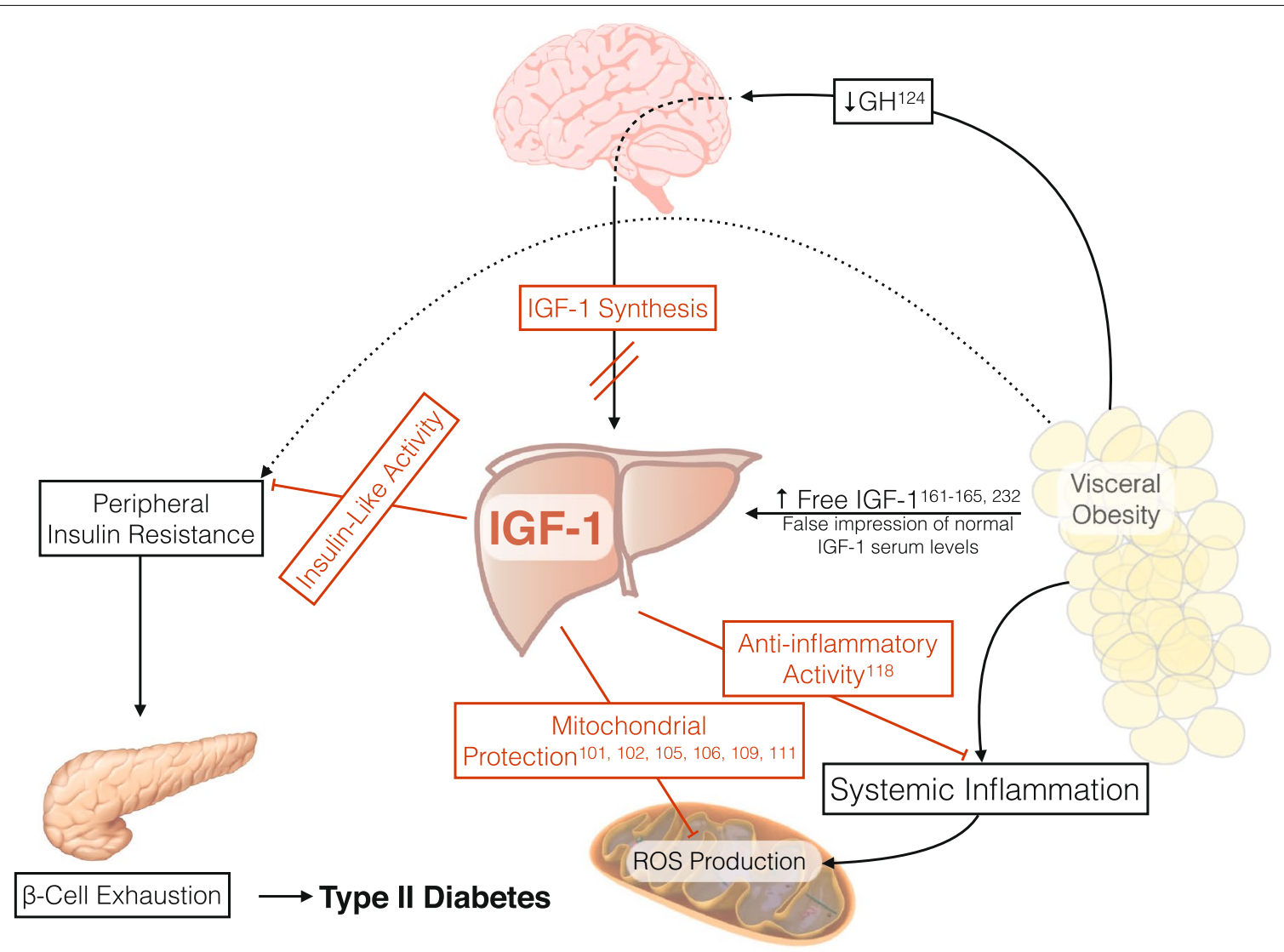

Fig. 2 Metabolic effects of IGF-1 and GH under pathological conditions. The figure summarises schematically some of the metabolic mechanisms altered in obesity and the role that IGF-1 and GH exert on them

Moreover, results from the aforementioned Framingham heart study also demonstrated the correlation between low IGF-1 and the increasing metabolic syndrome markers [221]. A good example is the finding that low circulating levels of IGF-1 are independently associated with hyperglycaemia and insulin resistance in adults [160, 230-232]. To the contrary, high to normal levels of circulating IGF-1 correlate with a rise in adiponectin levels and a reduced prevalence of MetS is found [233].

Since the liver is the major site of IGF-1 production, when steatosis develops lowering insulin sensitivity, the severity of steatosis at different stages of insulin resistance and metabolic syndrome seems to be correlated with worsened circulating IGF-1 levels [234]. In addition, low IGF-1 subjects in a study were found to possess up-regulated fatty acid metabolism along with downregulated GLUT-1 gene (in charge of glucose uptake in erythrocytes, brain endothelial cells, eye, peripheral nerve and also responsible for materno-placental glucose transfer) [210].

In summary, reconciling all discussed aspects relevant to insulin, IGF-1 improves insulin sensitivity by suppressing insulin and $\mathrm{GH}$ secretion and by improving insulin signalling indirectly reducing FFA flux.

When we look to IGF-1 levels in sera from T2D patients, the results found are very wide [235]. It must be considered that multiple factors interact to control IGF-1 levels, many of which are disturbed in T2D, namely: increased inflammatory cytokines, decreased hepatic insulin action due to resistance, concomitant changes in IGFBPs, and the effects of obesity. In addition, T2D is the result of a complex interaction of environmental and genetic factors, being difficult to establish the role of each one in the pathogenesis of diabetes and in the levels of IGF-1. In an experimental model, transgenic mice expressing a kinase-deficient IGF-1R $\beta$-subunit (thus displaying reduced signal transduction in both IGF-1R and hybrid receptors) developed diabetes early on life $[162,236]$. Also, mice carrying a genetic mutation that lack one of the igfir alleles $\left(i g f 1 r^{+-}\right.$) show a $10 \%$ reduction in post-natal growth, insulin resistance and glucose intolerance [237]. Additionally, infants born small for gestational age who exhibit low IGF-1 levels presented a higher risk for the onset and development of T2D in 
adult life than those born with normal weight [238, 239]. Nevertheless, it is noteworthy that the inverse correlation between IGF-1 and diabetes only prevails in younger individuals ( $<65$ years) [231], establishing that this deficiency can lead to MetS-as aging can be considered an IGF-1 deficiency condition [107].

Abnormal IGF-1 and GH levels have been proposed to play a key role in obesity [130, 240, 241]. Obese human and animal models are generally accompanied with abnormal circulating IGF-1 levels [130], as well as IGF-1/ IGFBP-3 ratio; and an inverse relationship between IGF-1 and visceral fat mass distribution has been described [242-246] as previously mentioned.

Moreover, some studies revealed that high fat diet promoted reactive oxygen species (ROS) and cytokine production, apoptosis, protein and mitochondrial damage, and reduced ATP content. These defects were accompanied by disrupted phosphorylation of the IRS, as well as down-regulated expression of mitochondrial proteins PPAR $\gamma$ co-activator $1 \alpha(\mathrm{PGC} 1 \alpha)$ and uncoupling protein-2 (UCP-2) [200]. All of these factors can be alleviated by the cytoprotective and anti-inflammatory actions of IGF-1 [105, 123, 247-249].

The culmination of all of these studies come to light with the finding of several (some reported and many from our group still publication pending) Laron's Syndrome (congenital IGF-1 deficiency or GH insensitivity) never treated patients who underwent progression to MetS and ultimately to T2D together with diabetic retinopathy when they reached their late $30 \mathrm{~s},[250,251]$.

\section{The role of insulin-like growth factor binding proteins in metabolic syndrome}

Recall that IGFBPs have a very important role, not only in modulating free IGF-1, half-life and localisation, but also by possessing IGF-independent activities mediated by their own receptors. Changes in IGFBPs have been correlated with certain parameters of MetS. For instance, low IGFBP-1 levels with high C-reactive protein values are strong predictors of MetS [252, 253]. Low IGFBP-2 also acts as a good marker for MetS along with high fasting glucose [254]. Even though the data is extensive it is not enough to explain any relationship between these molecules and the independent MetS factors, or any mechanism by which these molecules could be involved in the pathophysiology.

As a result of IGF-1 changes, IGFBPs are also altered in T2D [255]. Studies in prediabetes suggest that IGFBP-1 shows normal levels before developing T2D [256]. This may be caused by hyperinsulinaemia during the onset of the disease. Elevated insulin causes an increase of free serum IGF-1, nevertheless, as resistance to insulin progresses, the liver becomes insensitive to insulin-mediated suppression of IGFBP-1 [254, 256]. On the other hand, IGFBP-3 undergoes augmented proteolysis on diabetic patients which results in a sudden rise of free IGF-1 concentrations [257, 258].

Overexpressed IGFBP-1 in transgenic mice shows that its increase produces hyperinsulinaemia accompanied by glucose intolerance, and that this process is dependent upon IGFBP-1 phosphorylation state-which is increased in diabetes [259]. In another study it was found that after weight loss there is a rise in IGFBP-1 and IGFBP-2, both in children and adults [260, 261]. Considering that IGF-1 regulates IGFBP-1 and IGFBP-2, it is reasonable to conclude that early changes in insulin resistance alter their concentrations.

A recent study tested whether IGFBP-1 concentrations were able to predict the development of T2D in women. The outcomes showed that women with the lowest fasting IGFBP-1 at baseline had a higher risk for developing diabetes within 8 years, also showing an impaired IGFBP-1 suppression after oral glucose loading [256]. Conversely, in another study, 615 patients with IGF-1 values in the lower half of the normal range were closely observed during 4.5 years. It was found that there was an increased predisposition to develop glucose intolerance or T2D, and that this change was independent from IGFBP-1 [208].

Moreover, IGFBP-2 is decreased in obese patients and thus increasing free IGF-1 [262]. This fact is relevant as transgenic mice overexpressing IGFBP-2 were resistant to developing obesity when fed with high fat diet [174], suggesting that this molecule could have a direct effect on preadipocyte differentiation.

\section{IGF-1 treatment: future and limitations}

The FDA approved the use of rhIGF-1 (Mecasermin, Increlex $^{\mathrm{TM}}$ ) for treatment of severe primary IGF-1 deficiency in 2003. By the same time, the FDA approved the use of a equimolar combination of IGF-1 and IGFBP-3 (Mecasermin Rinfabate, Plex $^{\text {TM }}$ ), suggesting that it would be a better choice, seeming as it will require lower doses because of the augmented half-life of the molecule and "buffering" effect on concentration. Additionally this complex can bypass the IGF-2 displacement effect. Because IGFBP-3 also carries IGF-1, when IGF-1 is administered on its own, the carrier IGFBP-3 saturates with IGF-1 displacing IGF-2 and thus augments its free circulating concentration. However, subsequent studies revealed that no significant difference (among with some patient issues) could be observed, so now IGF-1 alone seems to be an efficient treatment. Recombinant human IGF-1 is usually synthesised in E. coli and subsequently purified. Its purification is a very insidious process that elevates the cost, and this fact in combination to the 
limited applicability that has been linked to date, elevates the price of the treatment.

The use of analogues has shown multiple and substantial clinical benefits along with metabolic improvement. A promising therapeutic approach being studied uses IGF-1 analogues such as PEG-IGF-1 [263], which offers promising protection against acute contraction-induced muscle injury.

To date several clinical trials have been conducted to test IGF-1 under several conditions and an infinity of animal models have been used to investigate its deficiency, treatment and to exploit its actions. Phase I studies from the late 1980s using IGF-1 to treat Laron's Syndrome (GH insensitivity) revealed effective increase in linear growth reaching adult heights using doses ranging from 80 to $240 \mu \mathrm{g} / \mathrm{kg} /$ day [264-268]. Different groups of patients and candidates for IGF-1 treatment have been those with an IGF-1 gene deletion and others with idiopathic short stature. Furthermore, phase II studies were undertaken to prove the efficacy of mecasermin rinfabate (IGF-1/ IGFBP-3) in paediatric severe burns and had promising outcomes when doses of 1-4 mg/kg/day [269-273] were used. Moreover IGF-1 was tested in patients with osteopenia/osteoporosis linked to anorexia nervosa and severe bone fractures with positive results utilising doses ranging from $30 \mu \mathrm{g}$ to $1 \mathrm{mg} / \mathrm{kg} /$ day for 2-9 months [274, 275].

When treating metabolic disorders with IGF-1, phase II trials until now conducted by Clemmons et al. including adult patients with either T1D or T2D treating with mecasermin rinfabate $(1-2 \mathrm{mg} / \mathrm{kg} /$ day for 14 days) showed lowered exogenous insulin requirements while improving glycaemic control. These results suggest improvement in insulin sensitivity, and moreover, no additional side effects to those found with placebo were observed in T1D, meanwhile in T2D patients oedema, jaw pain and arthralgias were $4 \%$ lower than previous reports [276, 277]. Evidence revealed that endogenous and exogenous IGF-1 administration protects against the onset and progression of diabetic cardiomyopathy [278, 279]. Consistent with this, patients with T2D responded to IGF-1 treatment with improved glucose tolerance, hyperinsulinaemia, and hyperlipidaemia as previously stated [280]. Up to date, limited information is available regarding obesity treatment by regulation of the $\mathrm{GH}$ IGF-1 system. Apart from all of these conditions tested under IGF-1 treatment, there are a number of other ones, among others: cystic fibrosis, AIDS, Chron's, multiple sclerosis and ALS - which are carefully revised by Rosenbloom [281].

Despite all the above-mentioned clinical benefits, the safety of long-term administration of this hormone remains controversial. There is supporting evidence reporting adverse effects from long-term rhIGF-1 treatment including neoplastic formation, cataract and renal hypertrophy, all of which seem to be the most severe effects observed and are usually rare [123, 282284]. Additionally these complications were transient, easily treated and tolerated without treatment discontinuation. More common side effects within the mentioned studies revealed mild to moderate effects like pain at site of injection or headache that was transient and disappeared after 1 month [268]. Other side effects reported ranged from lipohypertrophy at injection site, papilloedema (related to cranial hypertension), and facial nerve paralysis [276, 285], however symptoms did not prevail after treatment pause and restarting with lower doses [268]. The usual concern with regards to treatment with IGF-1 has historically been hypoglycaemia, however in the trials done so far it has not always occurred and had been lessened when administered with meals-it was also usually connected to an appearance in a loss of appetite [264, 286]. Another reported effect has been growth of lymphoid tissue (specially acromegaly and tonsillar hypertrophy), renal enlargement (with normal kidney function) and in rare cases facial coarsening of features and incremented hair growth [264].

Of further importance is the well-known effect of exercise in IGF-1 plasma level rise. It has been determined for years that after only single bouts of moderate to highintensity total IGF-1 plasma levels rise up to $\sim 10-30 \%$ and peak only after $5-10 \mathrm{~min}$ after the onset of the training [287]. This rapid increase has been argued to be due either to a release of IGF-1 stores in tissues or due to a proteolytic cleavage of IGFBP-3 either in the plasma or in tissue. Also it must be noted that during exercise $\mathrm{pH}$ drops dramatically and this affects negatively to IGFBPs affinity for IGF-1/2. It has been somehow elucidated that muscle tissue is the one movilising most of the IGF-1 from cells to plasma [288]. This muscle autocrine/paracrine/endocrine effect has various effects. Apart from the obvious differentiation of satellite cells, which may account for many of the beneficial actions of exercise training, without excluding the classical fat burning, cardiovascular tonification, neuroendocrine system activation and chronic inflammation grade lowering. These actions have been reviewed herein, but of special mention during exercise is the recruitment of hippocampal neuroprogenitor cells and improved neuroglia function $[289,290]$. Moreover, it has been recently proven that IGF-1 central administration also induced improvement in insulin sensitivity [291], meaning that this sudden rise after exercise or treatment could be of benefit not only in the periphery, but acting centrally. It must be reminded that in our experience, IGF-1 treatment does not only raise IGF-1 plasma levels, but also stimulates tissues to synthesise their own IGF-1 by a mechanism 
still not uncovered, aiming these mechanisms of central stimulation of peripheral improvement. These facts are in accordance with the perspective of this review which suggests the central and nuclear role of IGF-1 in metabolism. Because exercise is the current best option when it comes to restore metabolism and obesity inflammation problems (i.e. for MetS and T2D), and because exercise is one of the most potent IGF-1 synthesis/freeing mechanisms, it seems logical to correlate them and establish IGF-1 as a target for future options in the multifactorial treatment for metabolic syndrome.

Inasmuch, these complications have caused fear and controversy among studies and opinions towards the safety of the treatment even when there are findings supporting the need for further investigation in the field of metabolic disorders. In our experience, and the problem we often see in these trials, comes to the dosage administered which are brutally over the target of restoring the physiological normal levels of the hormone. All studies have been conducted using $80 \mu \mathrm{g}-4 \mathrm{mg} / \mathrm{kg} /$ day and ranging in a wide spectrum of lengths (weeks to months) and routes of administration. In all our previous murine studies we have used short cycles (10-14 days) of very low subcutaneal doses $(20 \mu \mathrm{g} / \mathrm{kg} /$ day $)$ after carefully assessing its circulating concentrations and using the minimum amount that was sufficient to adequately restore physiological values of the molecule. Using these concentration we have not yet perceived any of the reported adverse affects, including hypoglycaemias, retinopathies or any others. We are conscious of the limitations of the animal models [123], however in a clinical trial undertaken by this group to asses IGF-1 in liver function under cirrhosis with these same dosage $(20 \mu \mathrm{g} / \mathrm{kg} /$ day $)$ no side effects were reported and liver function greatly increased [108]. So, as this group has been experimenting over the last years, the problem with IGF-1 is a matter of dosage. Even more intriguing is the fact that none of the inclusion criteria for the above-mentioned studies encompassed tumour markers to potentially discard any ongoing or potential tumour process that, obviously, IGF-1 could accelerate. IGF-1, as happens with other hormone therapies (thyroid hormone or insulin), should never been used lightly without firstly assessing its deficiency (local, central or systemic) and secondly by ascertaining that no tumours are near to be generated. Careful monitoring during treatment should be carried out to guarantee a safe outcome.

\section{Conclusions}

It can be plainly concluded that everyday more IGF-1 roles are being unravelled which concern energy metabolism. In the present review we have summarised how the GH/IGF-1 axis, together with insulin and IGFBPs act in a coordinated manner to regulate energy flux and use. From our point of view, when this whole system becomes altered-whether obesity, genetics or environmental factors act to disrupt its symphony-insulin resistance, steatosis, MetS, and ultimately T2D may develop. In our experience and from the information presented in this review, IGF-1 acts as the cornerstone maintaining homeostasis in this system.

In the last decade several studies have been conducted which revealed the relevant role of IGF-1 in the development of MetS. Briefly, an inverse correlation between IGF-1 (IGF-1/IGFBP-3 ratio) circulating levels and several markers for obesity, MetS, T2D, and CVD has been found; and thus, it could indicate that low circulating levels of IGF-1 can lead to MetS and raise the risk for CVD and T2D. Nevertheless, more studies are needed to describe the exact mechanism by which IGF-1 impacts and interacts with other factors and hormones in order to develop each component of MetS, T2D and its cardiovascular consequences.

The axis GH/IGF-I is claiming a particular physiological understanding. Usually IGF-1 deficiency is associated to "GH resistance" or "GH insensibility" states. IGF-1 replacement therapy induced a restoration of the altered GH/IGF-1 axis by reducing circulating GH levels and recovering the somatostatinergic tone [292].

Low doses of IGF-1 seem to be able to restore circulating levels of this hormone promoting beneficial effects without undesired side effects (including hypoglycaemia). Secondary effects from IGF-1 therapy were reported after administration of doses higher than $60-80 \mu \mathrm{g} / \mathrm{kg} /$ day.

In summary, the implication of IGF-1 in glucose and lipid metabolism and its derangements when the GH/ insulin/IGF-1 axis balance fails is well documented. IGF/ IGFBPs level alterations in MetS have been, to some extent, observed, however the exact mechanism has not been elucidated-still it suggests a trend towards IGF-1 local or systemic deficiency or availability. It is still too early to consider IGF-1 as the key factor; rather, literature is providing the clue suggesting that it is a good endeavour to pursue in order to achieve an appropriate pharmacological target that could aim at reversing MetS in parallel with diet and exercise before it onsets T2D. This group only suggests such treatment when IGF-1 deficiency prevails, acting merely as a substitutive therapy, and never to exploit its multiple actions. Diet and exercise must be considered as the first line of "treatment", however if they fail to correct metabolic signalling, IGF-1 therapy seems to be promising at metabolic harmonisation. For this to become a fact, however, further carbon tracer, protein and gene expression studies, together with large patient protocols are needed to reveal the exact role of IGF-1 in the whole system; meaning, to establish a way 


\section{to direct IGF-1 supplementation towards exactly where it is needed in order to avoid MetS from progressing to more grave outcomes.}

\section{Abbreviations}

MetS: Metabolic syndrome; IGF-1: Insulin-like growth factor; CVD: Cardiovascular disease; T2D: Type 2 diabetes; RAS: Protooncogene protein P21; NAFLD Non-alcoholic fatty liver disease; OSA: Obstructive sleep apnea; HDL: High density lipoprotein; TG: Triglyceride; PI3K: Phosphatidylinositol-4,5-bisphosphate 3-kinase; AKT: Protein kinase B; GLUT: Glucose transporter; FA: Fatty acid; FFA: Free fatty ACID; IGF-1R: IGF-1 receptor; IGFBP: Insulin-like growth factor binding protein; IRS: Insulin receptor substrate; KO: Knock out; LDL: Low density lipoprotein; VLDL: Very low density lipoprotein; GH: Growth hormone; HOMA: Homeostasis model assessment; ROS: Reactive oxygen species.

\section{Authors' contributions}

GAA, JRI, and RGG participated in compiling data and elaborating the manuscript. ICC designed the review content, contributed to its writing and revised the conceptual contents until the final approval. All authors read and approved the final manuscript.

\section{Author details}

${ }^{1}$ Escuela de Medicina, Tecnologico de Monterrey, Avenida Morones Prieto No. 3000 Pte. Col. Los Doctores, 64710 Monterrey, Nuevo León, Mexico. ${ }^{2}$ Fundación de Investigación HM Hospitales, Madrid, Spain.

\section{Acknowledgements}

The authors would like to thank every researcher that contributed to the understanding of the close relationship between the IGF-1 deficiency and the Metabolic Syndrome establishment. The authors wish to express their gratitude to Ing. Karl Steinmetz and Tomas Lankenau for their English review of the manuscript and Jesús Ortiz Urbina for his generous help. This work was possible thank to the financial help of "Fundación de Investigación HM Hospitales" and "Tecnologico de Monterrey".

\section{Competing interests}

The authors declare that they have no competing interests.

Received: 9 October 2015 Accepted: 26 December 2015

Published online: 06 January 2016

\section{References}

1. Executive Summary of The Third Report of The. National Cholesterol Education Program (NCEP) expert panel on detection, evaluation, and treatment of high blood cholesterol in adults (adult treatment panel III). JAMA. 2001;285:2486-97.

2. Alberti KGMM, Eckel RH, Grundy SM, Zimmet PZ, Cleeman JI, Donato KA, Fruchart JC, James WPT, Loria CM, Smith SC. Harmonizing the metabolic syndrome: a joint interim statement of the international diabetes federation task force on epidemiology and prevention; National heart, lung, and blood institute; American heart association; World heart federation; International. Circulation. 2009;120:1640-5.

3. Pajunen P, Rissanen H, Härkänen T, Jula A, Reunanen A, Salomaa V. The metabolic syndrome as a predictor of incident diabetes and cardiovascular events in the Health 2000 Study. Diabetes Metab. 2010;36:395-401.

4. Balkau B, Charles MA. Comment on the provisional report from the WHO consultation. Diabetic Med. 1999;16:442-3.

5. Alberti KGMM, Zimmet PZ. Definition, diagnosis and classification of diabetes mellitus and its complications. Part 1: diagnosis and classification of diabetes mellitus. Provisional report of a WHO consultation. Diabet Med. 1998;15:539-53.

6. Alberti KGMM, Zimmet P, Shaw J. Metabolic syndrome-a new worldwide definition. A consensus statement from the International Diabetes Federation. Diabetic Med. 2006;23:469-80.
7. Hollman G, Kristenson M. The prevalence of the metabolic syndrome and its risk factors in a middle-aged Swedish population-mainly a function of overweight? Eur J Cardiovasc Nurs. 2008;7:21-6.

8. Cameron AJ, Magliano DJ, Zimmet PZ, Welborn T, Shaw JE. The metabolic syndrome in Australia: prevalence using four definitions. Diabetes Res Clin Pract. 2007;77:471-8.

9. Császár A, Kékes E, Abel T, Papp R, Kiss I, Balogh S. Prevalence of metabolic syndrome estimated by International Diabetes Federation criteria in a Hungarian population. Blood Press. 2006:15:101-6.

10. Deepa M, Farooq S, Datta M, Deepa R, Mohan V. Prevalence of metabolic syndrome using WHO, ATPIII and IDF definitions in Asian Indians: the Chennai Urban Rural Epidemiology Study (CURES-34). Diabetes Metab Res Rev. 2007;23:127-34

11. Jeppesen J, Hansen TW, Rasmussen S, Ibsen H, Torp-Pedersen C, Madsbad S. Insulin resistance, the metabolic syndrome, and risk of incident cardiovascular disease. A population-based study. J Am Coll Cardiol. 2007:49:2112-9

12. Lorenzo C, Serrano-Ríos M, Martínez-Larrad MT, González-Sánchez J, Seclén S, Villena A, Gonzalez-Villalpando C, Williams K, Haffner SM. Geographic variations of the International Diabetes Federation and the National Cholesterol Education Program-Adult Treatment Panel III definitions of the metabolic syndrome in nondiabetic subjects. Diabetes Care. 2006;29:685-91.

13. Harzallah F, Alberti H, Ben Khalifa F. The metabolic syndrome in an Arab population: a first look at the new International Diabetes Federation criteria. Diabet Med. 2006:23:441-4.

14. Chien KL, Lee BC, Hsu HC, Lin HJ, Chen MF, Lee YT. Prevalence, agreement and classification of various metabolic syndrome criteria among ethnic Chinese: a report on the hospital-based health diagnosis of the adult population. Atherosclerosis. 2008;196:764-71.

15. Zabetian A, Hadaegh F, Azizi F. Prevalence of metabolic syndrome in Iranian adult population, concordance between the IDF with the ATPIII and the WHO definitions. Diabetes Res Clin Pract. 2007:77:251-7.

16. Ilanne-Parikka P, Eriksson JG, Lindström J, Hämäläinen $H$, Keinänen-Kiukaanniemi S, Laakso M, Louheranta A, Mannelin M, Rastas M, Salminen V, Aunola S, Sundvall J, Valle T, Lahtela J, Uusitupa M, Tuomilehto J. Prevalence of the metabolic syndrome and its components: findings from a Finnish general population sample and the Diabetes Prevention Study cohort. Diabetes Care. 2004;27:2135-40.

17. Jørgensen ME, Bjerregaard P, Gyntelberg F, Borch-Johnsen K, Backer $\mathrm{V}$, Becker U, Jørgensen T, Mulvad G. Prevalence of the metabolic syndrome among the Inuit in Greenland. A comparison between two proposed definitions. Diabet Med. 2004;21:1237-42.

18. Liu J, Hanley AJG, Young TK, Harris SB, Zinman B. Characteristics and prevalence of the metabolic syndrome among three ethnic groups in Canada. Int J Obes (Lond). 2006;30:669-76.

19. Khader Y, Bateiha A, El-Khateeb M, Al-Shaikh A, Ajlouni K. High prevalence of the metabolic syndrome among Northern Jordanians. Diabetes Complications. 2007;21:214-9.

20. Aguilar-Salinas CA, Rojas R, Gómez-Pérez FJ, Valles V, Ríos-Torres JM, Franco A, Olaiz G, Rull JA, Sepúlveda J. High prevalence of metabolic syndrome in Mexico. Arch Med Res. 2004;35:76-81.

21. Al-Lawati JA, Mohammed AJ, Al-Hinai HO Jousilahti P. Prevalence of the metabolic syndrome among Omani adults. Diabetes Care. 2003;26:1781-5

22. Abdul-Rahim HF, Husseini A, Bjertness E, Giacaman R, Gordon NH, Jervell $J$. The metabolic syndrome in the West Bank population: an urban-rural comparison. Diabetes Care. 2001;24:275-9.

23. Medina-Lezama J, Zea-Diaz H, Morey-Vargas OL, Bolaños-Salazar JF, Muñoz-Atahualpa E, Postigo-MacDowall M, Corrales-Medina F, Valdivia-Ascuña Z, Cuba-Bustinza C, Paredes-Díaz S, Villalobos-Tapia P, Chirinos-Pacheco J, Goldberg RB, Chirinos JA. Prevalence of the metabolic syndrome in Peruvian Andean hispanics: the PREVENCION study. Diabetes Res Clin Pract. 2007;78:270-81.

24. Tanchoco CC, Cruz AJ, Duante CA, Litonjua AD. Prevalence of metabolic syndrome among Filipino adults aged 20 years and over. Asia Pac J Clin Nutr. 2003;12:271-6.

25. Jones ED, Ivanov LL, Wallace DC, VonCannon L. Examining the metabolic syndrome in Russia. Int J Nurs Pract. 2006;12:260-6. 
26. Lee WY, Park JS, Noh SY, Rhee EJ, Kim SW, Zimmet PZ. Prevalence of the metabolic syndrome among 40,698 Korean metropolitan subjects. Diabetes Res Clin Pract. 2004;65:143-9.

27. Kozan O, Oguz A, Abaci A, Erol C, Ongen Z, Temizhan A, Celik S. Prevalence of the metabolic syndrome among Turkish adults. Eur J Clin Nutr. 2007;61:548-53.

28. Ford ES. Prevalence of the metabolic syndrome defined by the international diabetes federation among adults in the U.S. Diabetes Care. 2005;28:2745-9.

29. Hwang L-C, Bai C-H, Chen C-J. Prevalence of obesity and metabolic syndrome in Taiwan. J Formos Med Assoc. 2006;105:626-35.

30. Ford ES, Giles WH, Dietz WH. Prevalence of the metabolic syndrome among US adults: findings from the third National Health and Nutrition Examination Survey. JAMA. 2002;287:356-9.

31. Ford ES, Giles WH. A comparison of the prevalence of the metabolic syndrome using two proposed definitions. Diabetes Care. 2003;26:575-81.

32. Park Y-W, Zhu S, Palaniappan L, Heshka S, Carnethon MR, Heymsfield SB. The metabolic syndrome: prevalence and associated risk factor findings in the US population from the Third National Health and Nutrition Examination Survey, 1988-1994. Arch Intern Med. 2003;163:427-36.

33. Ford ES, Giles WH, Mokdad AH. Increasing prevalence of the metabolic syndrome among US adults. Diabetes Care. 2004;27:2444-9.

34. Leite MLC, Nicolosi A, Firmo JOA, Lima-Costa MF. Features of metabolic syndrome in non-diabetic Italians and Brazilians: a discriminant analysis. Int J Clin Pract. 2007;61:32-8.

35. Flegal KM, Carroll MD, Kuczmarski RJ, Johnson CL. Overweight and obesity in the United States: prevalence and trends, 1960-1994. Int J Obes Relat Metab Disord. 1998:22:39-47.

36. Mokdad AH, Bowman BA, Ford ES, Vinicor F, Marks JS, Koplan JP. The continuing epidemics of obesity and diabetes in the United States. JAMA. 2001;286:1195-200.

37. Grundy SM. Metabolic syndrome pandemic. Arterioscler Thromb Vasc Biol. 2008;28:629-36.

38. Cornier M-A, Dabelea D, Hernandez TL, Lindstrom RC, Steig AJ, Stob NR, Van Pelt RE, Wang H, Eckel RH. The metabolic syndrome. Endocr Rev. 2008;29:777-822

39. Cameron AJ, Shaw JE, Zimmet PZ. The metabolic syndrome: prevalence in worldwide populations. Endocrinol Metab Clin N Am. 2004;33:351-75.

40. Lakka H-M, Laaksonen DE, Lakka TA, Niskanen LK, Kumpusalo E, Tuomilehto J, Salonen JT. The metabolic syndrome and total and cardiovascular disease mortality in middle-aged men. JAMA. 2002;288:2709-16.

41. Isomaa B, Almgren P, Tuomi T, Forsén B, Lahti K, Nissén M, Taskinen MR, Groop L. Cardiovascular morbidity and mortality associated with the metabolic syndrome. Diabetes Care. 2001;24:683-9.

42. Sattar N, Gaw A, Scherbakova O, Ford I, O'Reilly DSJ, Haffner SM, Isles C, Macfarlane PW, Packard CJ, Cobbe SM, Shepherd J. Metabolic syndrome with and without C-reactive protein as a predictor of coronary heart disease and diabetes in the West of Scotland coronary prevention study. Circulation. 2003;108:414-9.

43. Girman CJ, Rhodes T, Mercuri M, Pyörälä K, Kjekshus J, Pedersen TR, Beere PA, Gotto AM, Clearfield M. The metabolic syndrome and risk of major coronary events in the Scandinavian Simvastatin Survival Study (4S) and the Air Force/Texas Coronary Atherosclerosis Prevention Study (AFCAPS/TexCAPS). Am J Cardiol. 2004;93:136-41.

44. Malik S, Wong ND, Franklin SS, Kamath TV, L'Italien GJ, Pio JR, Williams GR. Impact of the metabolic syndrome on mortality from coronary heart disease, cardiovascular disease, and all causes in United States adults. Circulation. 2004;110:1245-50.

45. Olijhoek JK, van der Graaf Y, Banga J-D, Algra A, Rabelink TJ, Visseren FLJ. The metabolic syndrome is associated with advanced vascular damage in patients with coronary heart disease, stroke, peripheral arterial disease or abdominal aortic aneurysm. Eur Heart J. 2004;25:342-8.

46. Alexander CM, Landsman PB, Teutsch SM, Haffner SM. NCEP-defined metabolic syndrome, diabetes, and prevalence of coronary heart disease among NHANES III participants age 50 years and older. Diabetes. 2003;52:1210-4.

47. Ninomiya JK, L'Italien G, Criqui MH, Whyte JL, Gamst A, Chen RS. Association of the metabolic syndrome with History of Myocardial Infarction and Stroke in the Third National Health and Nutrition Examination Survey. Circulation. 2004;109:42-6.

48. McNeill AM, Rosamond WD, Girman CJ, Golden SH, Schmidt MI, East HE, Ballantyne CM, Heiss G. The metabolic syndrome and 11-year risk of incident cardiovascular disease in the atherosclerosis risk in communities study. Diabetes Care. 2005;28:385-90.

49. Solymoss BC, Bourassa MG, Lespérance J, Levesque S, Marcil M, Varga S, Campeau L. Incidence and clinical characteristics of the metabolic syndrome in patients with coronary artery disease. Coron Artery Dis. 2003;14:207-12.

50. Turhan H, Yasar AS, Basar N, Bicer A, Erbay AR, Yetkin E. High prevalence of metabolic syndrome among young women with premature coronary artery disease. Coron Artery Dis. 2005;16:37-40.

51. Dekker JM, Girman C, Rhodes T, Nijpels G, Stehouwer CDA, Bouter LM, Heine RJ. Metabolic syndrome and 10-year cardiovascular disease risk in the Hoorn Study. Circulation. 2005;112:666-73.

52. Wannamethee SG, Shaper AG, Lennon L, Morris RW. Metabolic syndrome vs Framingham risk score for prediction of coronary heart disease, stroke, and type 2 diabetes mellitus. Arch Intern Med. 2005; 165:2644-50.

53. Hong $Y$, Jin X, Mo J, Lin H-M, Duan Y, Pu M, Wolbrette DL, Liao D. Metabolic syndrome, its preeminent clusters, incident coronary heart disease and all-cause mortality-results of prospective analysis for the Atherosclerosis Risk in Communities study. J Intern Med. 2007;262:113-22.

54. Meigs JB, Rutter MK, Sullivan LM, Fox CS, D'Agostino RB, Wilson PWF. Impact of insulin resistance on risk of type 2 diabetes and cardiovascular disease in people with metabolic syndrome. Diabetes Care. 2007;30:1219-25.

55. Hu G, Qiao Q, Tuomilehto J, Balkau B, Borch-Johnsen K, Pyorala K. Prevalence of the metabolic syndrome and its relation to all-cause and cardiovascular mortality in nondiabetic European men and women. Arch Intern Med. 2004;164:1066-76.

56. Pouliot MC, Després JP, Nadeau A, Moorjani S, Prud'Homme D, Lupien PJ, Tremblay A, Bouchard C. Visceral obesity in men: associations with glucose tolerance, plasma insulin, and lipoprotein levels. Diabetes. 1992. 41:826-834.

57. Arner P. Not all fat is alike. Lancet. 1998;351:1301-2.

58. Large V, Arner P. Regulation of lipolysis in humans. Pathophysiological modulation in obesity, diabetes, and hyperlipidaemia. Diabetes Metab. 1998:24:409-18.

59. Bergman RN, Kim SP, Hsu IR, Catalano KJ, Chiu JD, Kabir M, Richey JM, Ader M: Abdominal obesity: role in the pathophysiology of metabolic disease and cardiovascular risk. Am J Med. 2007;120(2 suppl 1):S3-S8 (discussion S29-32)

60. de Luca C, Olefsky JM. Inflammation and insulin resistance. FEBS Lett. 2008;582:97-105.

61. Klein BEK, Klein R, Lee KE. Components of the metabolic syndrome and risk of cardiovascular disease and diabetes in Beaver Dam. Diabetes Care. 2002:25:1790-4.

62. Sattar N, McConnachie A, Shaper AG, Blauw GJ, Buckley BM, de Craen AJ, Ford I, Forouhi NG, Freeman DJ, Jukema JW, Lennon L, Macfarlane PW, Murphy MB, Packard CJ, Stott DJ, Westendorp RG, Whincup PH, Shepherd J, Wannamethee SG. Can metabolic syndrome usefully predict cardiovascular disease and diabetes? Outcome data from two prospective studies. Lancet. 2008;371:1927-35.

63. Laaksonen DE, Lakka H-M, Niskanen LK, Kaplan GA, Salonen JT, Lakka TA. Metabolic syndrome and development of diabetes mellitus: application and validation of recently suggested definitions of the metabolic syndrome in a prospective cohort study. Am J Epidemiol. 2002;156:1070-7.

64. Hanson RL, Imperatore G, Bennett PH, Knowler WC. Components of the "metabolic syndrome" and incidence of type 2 diabetes. Diabetes. 2002;51:3120-7.

65. Lebovitz HE. Type 2 diabetes: an overview. Clin Chem. 1999:45(8 Pt 2):1339-45.

66. Grundy SM. Metabolic syndrome: Connecting and reconciling cardiovascular and diabetes worlds. J Am Coll Cardiol. 2006;47:1093-100.

67. Ford ES, Li C, Sattar N. Metabolic syndrome and incident diabetes. Diabetes Care. 2008;31:1898-904.

68. Kim HJ, Kim HJ, Lee KE, Kim DJ, Kim SK, Ahn CW, Lim S-K, Kim KR, Lee HC, Huh KB, Cha BS. Metabolic significance of nonalcoholic 
fatty liver disease in nonobese, nondiabetic adults. Arch Intern Med. 2004;164:2169-75.

69. Kotronen A, Westerbacka J, Bergholm R, Pietiläinen KH, Yki-Järvinen H. Liver fat in the metabolic syndrome. J Clin Endocrinol Metab. 2007:92:3490-7.

70. Parish JM, Adam T, Facchiano L. Relationship of metabolic syndrome and obstructive sleep apnea. J Clin Sleep Med. 2007;3:467-72.

71. Gami AS, Somers VK. Obstructive sleep apnoea, metabolic syndrome, and cardiovascular outcomes. Eur Heart J. 2004;25:709-11.

72. Gruber A, Horwood F, Sithole J, Ali NJ, Idris I. Obstructive sleep apnoea is independently associated with the metabolic syndrome but not insulin resistance state. Cardiovasc Diabetol. 2006;5:22.

73. Tasali E, Van Cauter E. Sleep-disordered breathing and the current epidemic of obesity: consequence or contributing factor? Am J Respir Crit Care Med. 2002;165:562-3.

74. Cizza G, Skarulis M, Mignot E. A link between short sleep and obesity: building the evidence for causation. Sleep. 2005;28:1217-20.

75. Vgontzas AN, Bixler EO, Chrousos GP. Sleep apnea is a manifestation of the metabolic syndrome. Sleep Med Rev. 2005;9:211-24.

76. Wolk R, Somers VK. Sleep and the metabolic syndrome. Exp Physiol. 2007:92:67-78.

77. Ip MSM, Lam B, Ng MMT, Lam WK, Tsang KWT, Lam KSL. Obstructive sleep apnea is independently associated with insulin resistance. Am J Respir Crit Care Med. 2002;165:670-6.

78. The prevalence of retinopathy in impaired glucose tolerance and recent-onset diabetes in the Diabetes Prevention Program. Diabet Med. 2007:24:137-44

79. Tyrberg M, Melander A, Lövestam-Adrian M, Lindblad U. Retinopathy in subjects with impaired fasting glucose: the NANSY-Eye baseline report. Diabetes Obes Metab. 2008;10:646-51.

80. Rashidi A, Ghanbarian A, Azizi F. Are patients who have metabolic syndrome without diabetes at risk for developing chronic kidney disease? Evidence based on data from a large cohort screening population. Clin J Am Soc Nephrol. 2007;2:976-83.

81. Kurella M, Lo JC, Chertow GM. Metabolic syndrome and the risk for chronic kidney disease among nondiabetic adults. J Am Soc Nephrol. 2005;16:2134-40.

82. Ninomiya T, Kiyohara Y, Kubo M, Yonemoto K, Tanizaki Y, Doi Y, Hirakata H, lida M. Metabolic syndrome and CKD in a general Japanese population: the Hisayama Study. Am J Kidney Dis. 2006;48:383-91.

83. Klausen KP, Parving H-H, Scharling H, Jensen JS. The association between metabolic syndrome, microalbuminuria and impaired renal function in the general population: impact on cardiovascular disease and mortality. J Intern Med. 2007;262:470-8.

84. Lin C-C, Liu C-S, Li T-C, Chen C-C, Li C-I, Lin W-Y. Microalbuminuria and the metabolic syndrome and its components in the Chinese population. Eur J Clin Invest. 2007;37:783-90.

85. Diamantopoulos EJ, Andreadis EA, Tsourous GI, Katsanou PM, Georgiopoulos DX, Nestora KC, Raptis SA. Early vascular lesions in subjects with metabolic syndrome and prediabetes. Int Angiol. 2006;25:179-83.

86. Gordon Smith A, Robinson Singleton J. Idiopathic neuropathy, prediabetes and the metabolic syndrome. J Neurol Sci. 2006;242(1-2 SPEC. ISS.):9-14.

87. Flier JS, Underhill LH, Le Roith D. Insulin-like growth factors. N Engl J Med. 1997;336:633-40.

88. Rinderknecht $E$, Humbel RE. The amino acid sequence of human insulin-like growth factor I and its structural homology with proinsulin. J Biol Chem. 1978;253:2769-76.

89. Berelowitz M, Szabo M, Frohman LA, Firestone S, Chu L, Hintz RL. Somatomedin-C mediates growth hormone negative feedback by effects on both the hypothalamus and the pituitary. Science. 1981;212:1279-81.

90. Ohlsson C, Mohan S, Sjögren K, Tivesten Å, Isgaard J, Isaksson O, Jansson $\mathrm{JO}$, Svensson J. The role of liver-derived insulin-like growth factor-I. Endocr Rev. 2009;30:494-535.

91. Böni-Schnetzler M, Schmid C, Meier PJ, Froesch ER. Insulin regulates insulin-like growth factor I mRNA in rat hepatocytes. Am J Physiol. 1991;260:E846-51

92. D'Ercole AJ, Stiles AD, Underwood LE. Tissue concentrations of somatomedin C: further evidence for multiple sites of synthesis and paracrine or autocrine mechanisms of action. Proc Natl Acad Sci USA. 1984:81:935-9.

93. Clemmons DR. Role of insulin-like growth factor binding proteins in controlling IGF actions. Mol Cell Endocrinol. 1998;140:19-24.

94. Rajpathak SN, Gunter MJ, Wylie-Rosett J, Ho GYF, Kaplan RC, Muzumdar $R$, Rohan TE, Strickler HD. The role of insulin-like growth factor-l and its binding proteins in glucose homeostasis and type 2 diabetes. Diabetes Metab Res Rev. 2009;25:3-12.

95. Rosenfeld RG, Hwa V, Wilson E, Plymate SR, Oh Y. The insulin-like growth factor-binding protein superfamily. Growth Horm IGF Res. 2000;10(suppl A):S16-17.

96. Liu J, Kosma V-M, Vänttinen T, Hydén-Granskog C, Voutilainen R. Gonadotrophins inhibit the expression of insulin-like growth factor binding protein-related protein-2 mRNA in cultured human granulosa-luteal cells. Mol Hum Reprod. 2002;8:136-41.

97. López-Bermejo A, Khosravi J, Corless CL, Krishna RG, Diamandi A, Bodani U, Kofoed EM, Graham DL, Hwa V, Rosenfeld RG. Generation of anti-insulin-like growth factor-binding protein-related protein 1 (IGFBPrP1/MAC25) monoclonal antibodies and immunoassay: quantification of IGFBP-rP1 in human serum and distribution in human fluids and tissues. J Clin Endocrinol Metab. 2003;88:3401-8.

98. Chitnis MM, Yuen JSP, Protheroe AS, Pollak M, Macaulay VM. The type 1 insulin-like growth factor receptor pathway. Clin Cancer Res. 2008;14:6364-70.

99. LeRoith D, Werner H, Beitner-Johnson D, Roberts CT. Molecular and cellular aspects of the insulin-like growth factor I receptor. Endocr Rev. 1995;16:143-63.

100. Kim JJ, Accili D. Signalling through IGF-I and insulin receptors: where is the specificity? Growth Horm IGF Res. 2002;12:84-90.

101. Garcia-Fernandez M, Sierra I, Puche JE, Guerra L, Castilla-Cortazar I. Liver mitochondrial dysfunction is reverted by insulin-like growth factor II (IGF-II) in aging rats. J TransI Med. 2011;9:123.

102. Castilla-Cortázar I, García-Fernández M, Delgado G, Puche JE, Sierra I, Barhoum R, González-Barón S. Hepatoprotection and neuroprotection induced by low doses of IGF-II in aging rats. J TransI Med. 2011:9:103.

103. Wolf E, Hoeflich A, Lahm H. What is the function of IGF-II in postnatal life? Answers from transgenic mouse models. Growth Horm IGF Res. 1998;8:185-93.

104. Wang KCW, Tosh DN, Zhang S, McMillen IC, Duffield JA, Brooks DA, Morrison JL. IGF-2R-Gaq signaling and cardiac hypertrophy in the low-birth-weight lamb. Am J Physiol Regul Integr Comp Physiol. 2015;308:R627-35.

105. Pérez R, García-Fernández M, Díaz-Sánchez M, Puche JE, Delgado G, Conchillo M, Muntané J, Castilla-Cortázar Larrea I. Mitochondrial protection by low doses of insulin-like growth factor-l in experimental cirrhosis. World J Gastroenterol. 2008;14:2731-9.

106. Puche JE, García-Fernández M, Muntané J, Rioja J, González-Barón S, Cortazar IC. Low doses of insulin-like growth factor-I induce mitochondrial protection in aging rats. Endocrinology. 2008;149:2620-7.

107. García-Fernández M, Delgado G, Puche JE, González-Barón S, Cortázar IC. Low doses of insulin-like growth factor I improve insulin resistance, lipid metabolism, and oxidative damage in aging rats. Endocrinology. 2008; 149:2433-42.

108. Conchillo M, De Knegt RJ, Payeras M, Quiroga J, Sangro B, Herrero Jl, Castilla-Cortazar I, Frystyk J, Flyvbjerg A, Yoshizawa C, Jansen PLM, Scharschmidt B, Prieto J. Insulin-like growth factor I (IGF-I) replacement therapy increases albumin concentration in liver cirrhosis: results of a pilot randomized controlled clinical trial. J Hepatol. 2005;43:630-6.

109. García-Fernández M, Castilla-Cortázar I, Díaz-Sanchez M, Navarro I, Puche JE, Castilla A, Casares AD, Clavijo E, González-Barón S. Antioxidant effects of insulin-like growth factor-I (IGF-I) in rats with advanced liver cirrhosis. BMC Gastroenterol. 2005;5:7.

110. Castilla-Cortázar I, Pascual M, Urdaneta E, Pardo J, Puche JE, Vivas B, Díaz-Casares A, García M, Díaz-Sánchez M, Varela-Nieto I, Castilla A, González-Barón S. Jejunal microvilli atrophy and reduced nutrient transport in rats with advanced liver cirrhosis: improvement by Insulin-like Growth Factor I. BMC Gastroenterol. 2004;4:12.

111. García-Fernández M, Castilla-Cortázar I, Díaz-Sánchez M, Díez Caballero F, Castilla A, Díaz Casares A, Varela-Nieto I, González-Barón S. Effect of IGF-I on total serum antioxidant status in cirrhotic rats. J Physiol Biochem. 2003;59:145-6. 
112. Mirpuri E, García-Trevijano ER, Castilla-Cortazar I, Berasain C, Quiroga J, Rodriguez-Ortigosa C, Mato JM, Prieto J, Avila MA. Altered liver gene expression in CCl4-cirrhotic rats is partially normalized by insulin-like growth factor-I. Int J Biochem Cell Biol. 2002;34:242-52.

113. Muguerza B, Castilla-Cortázar I, García M, Quiroga J, Santidrián S, Prieto J. Antifibrogenic effect in vivo of low doses of insulin-like growth factorI in cirrhotic rats. Biochim Biophys Acta. 2001;1536:185-95.

114. Pascual M, Castilla-Cortazar I, Urdaneta E, Quiroga J, Garcia M, Picardi A, Prieto J. Altered intestinal transport of amino acids in cirrhotic rats: the effect of insulin-like growth factor-I. Am J Physiol Gastrointest Liver Physiol. 2000;279:G319-24.

115. Castilla-Cortazar I, Garcia M, Quiroga J, Diez N, Diez-Caballero F, Calvo A, Diaz M, Prieto J. Insulin-like growth factor-I reverts testicular atrophy in rats with advanced cirrhosis. Hepatology. 2000;31:592-600.

116. Castilla-Cortazar I, Garcia M, Muguerza B, Quiroga J, Perez R, Santidrian S, Prieto J. Hepatoprotective effects of insulin-like growth factor I in rats with carbon tetrachloride-induced cirrhosis. Gastroenterology. 1997;113:1682-91.

117. Zick Y. Uncoupling insulin signalling by serine/threonine phosphorylation: a molecular basis for insulin resistance. Biochem Soc Trans. 2004;32(Pt 5):812-6.

118. Wang X, Proud CG. mTORC2 is a tyrosine kinase. Cell Res. 2015.

119. Denley A, Carroll JM, Brierley GV, Cosgrove L, Wallace J, Forbes B, Roberts CT. Differential activation of insulin receptor substrates 1 and 2 by insulin-like growth factor-activated insulin receptors. Mol Cell Biol. 2007;27:3569-77.

120. Landis J, Shaw LM. Insulin receptor substrate 2-mediated phosphatidylinositol 3-kinase signaling selectively inhibits glycogen synthase kinase $3 \beta$ to regulate aerobic glycolysis. J Biol Chem. 2014;289:18603-13.

121. Hanke S, Mann M. The phosphotyrosine interactome of the insulin receptor family and its substrates IRS-1 and IRS-2. Mol Cell Proteomics. 2009;8:519-34.

122. Kim B, Feldman EL. Insulin receptor substrate (IRS)-2, not IRS-1, protects human neuroblastoma cells against apoptosis. Apoptosis. 2009; 14:665-73

123. Puche JE, Castilla-Cortázar I. Human conditions of insulin-like growth factor-I (IGF-I) deficiency. J Transl Med. 2012;10:224.

124. Smith TJ. Insulin-like growth factor-I regulation of immune function: a potential therapeutic target in autoimmune diseases? Pharmacol Rev. 2010;62:199-236.

125. Heilbronn LK, Campbell LV. Adipose tissue macrophages, low grade inflammation and insulin resistance in human obesity. Curr Pharm Des. 2008;14:1225-30.

126. Grounds MD, Radley HG, Gebski BL, Bogoyevitch MA, Shavlakadze T. Implications of cross-talk between tumour necrosis factor and insulinlike growth factor-1 signalling in skeletal muscle. Clin Exp Pharmacol Physiol. 2008;35:846-51.

127. O'Connor JC, McCusker RH, Strle K, Johnson RW, Dantzer R, Kelley KW. Regulation of IGF-I function by proinflammatory cytokines: at the interface of immunology and endocrinology. Cell Immunol. 2008;252:91-110.

128. Merimee TJ, Zapf J, Froesch ER. Insulin-like growth factors in the fed and fasted states. J Clin Endocrinol Metab. 1982;55:999-1002.

129. Clemmons DR. Involvement of insulin-like growth factor-l in the control of glucose homeostasis. Curr Opin Pharmacol. 2006;6:620-5.

130. Franco C, Bengtsson B-A, Johannsson G. The GH/IGF-1 axis in obesity: physiological and pathological aspects. Metab Syndr Relat Disord. 2006;4:51-6.

131. Pao Cl, Farmer PK, Begovic S, Goldstein S, Wu GJ, Phillips LS. Expression of hepatic insulin-like growth factor-I and insulin-like growth factorbinding protein-1 genes is transcriptionally regulated in streptozotocindiabetic rats. Mol Endocrinol. 1992;6:969-77.

132. Federici M, Porzio O, Zucaro L, Giovannone B, Borboni P, Marini MA, Lauro D, Sesti G. Increased abundance of insulin/IGF-I hybrid receptors in adipose tissue from NIDDM patients. Mol Cell Endocrinol. 1997;135:41-7.

133. Federici M, Giaccari A, Hribal ML, Giovannone B, Lauro D, Morviducci L, Pastore L, Tamburrano G, Lauro R, Sesti G. Evidence for glucose/hexosamine in vivo regulation of insulin/IGF-I hybrid receptor assembly. Diabetes. 1999:48:2277-85.
134. Mauras N, Beaufrere B. Recombinant human insulin-like growth factor-l enhances whole body protein anabolism and significantly diminishes the protein catabolic effects of prednisone in humans without a diabetogenic effect. J Clin Endocrinol Metab. 1995;80:869-74.

135. Mauras N, Haymond MW. Are the metabolic effects of GH and IGF-I separable? Growth Horm IGF Res. 2005;15:19-27.

136. Ren J, Anversa P. The insulin-like growth factor I system : physiological and pathophysiological implication in cardiovascular diseases associated with metabolic syndrome. Biochem Pharmacol 2015;93:409-17.

137. Laager R, Ninnis R, Keller U. Comparison of the effects of recombinant human insulin-like growth factor-I and insulin on glucose and leucine kinetics in humans. J Clin Invest. 1993;92:1903-9.

138. Elahi D, McAloon-Dyke M, Fukagawa NK, Sclater AL, Wong GA, Shannon RP, Minaker KL, Miles JM, Rubenstein AH, Vandepol CJ. Effects of recombinant human IGF-I on glucose and leucine kinetics in men. Am J Physiol. 1993;265:E831-8.

139. Russell-Jones DL, Bates AT, Umpleby AM, Hennessy TR, Bowes SB, Hopkins KD, Jackson N, Kelly J, Shojaee-Moradie F, Jones RH. A comparison of the effects of igf-i and insulin on glucose metabolism, fat metabolism and the cardiovascular system in normal human volunteers. Eur J Clin Invest. 1995;25:403-11.

140. Boulware SD, Tamborlane WV, Rennert NJ, Gesundheit N, Sherwin RS. Comparison of the metabolic effects of recombinant human insulinlike growth factor-I and insulin. Dose-response relationships in healthy young and middle-aged adults. J Clin Invest. 1994;93:1131-9.

141. Frystyk J, Grøfte T, Skjaerbaek C, Orskov H. The effect of oral glucose on serum free insulin-like growth factor-I and -II in health adults. J Clin Endocrinol Metab. 1997;82:3124-7.

142. Sakai K, Lowman HB, Clemmons DR. Increases in free, unbound insulin-like growth factor I enhance insulin responsiveness in human hepatoma G2 cells in culture. J Biol Chem. 2002;277:13620-7.

143. Zenobi PD, Guler HP, Zapf J, Froesch ER. Insulin-like growth factors in the Göttinger miniature-pig. Acta Endocrinol (Copenh). 1988;117:343-52.

144. Zapf J, Hauri C, Waldvogel M, Froesch ER. Acute metabolic effects and half-lives of intravenously administered insulinlike growth factors I and II in normal and hypophysectomized rats. J Clin Invest. 1986;77:1768-75.

145. Schmid C, Bianda T, Zwimpfer C, Zapf J, Wiesli P. Changes in insulin sensitivity induced by short-term growth hormone $(\mathrm{GH})$ and insulinlike growth factor I (IGF-I) treatment in GH-deficient adults are not associated with changes in adiponectin levels. Growth Horm IGF Res. 2005; 15:300-3.

146. Zenobi PD, Graf S, Ursprung H, Froesch ER. Effects of insulin-like growth factor-I on glucose tolerance, insulin levels, and insulin secretion. J Clin Invest. 1992;89:1908-13.

147. Guler HP, Zapf J, Froesch ER. Short-term metabolic effects of recombinant human insulin-like growth factor I in healthy adults. N Engl J Med. 1987;317:137-40

148. Morrow LA, O'Brien MB, Moller DE, Flier JS, Moses AC. Recombinant human insulin-like growth factor-l therapy improves glycemic control and insulin action in the type A syndrome of severe insulin resistance. J Clin Endocrinol Metab. 1994;79:205-10.

149. Zenobi PD, Glatz Y, Keller A, Graf S, Jaeggi-Groisman SE, Riesen WF, Schoenle EJ, Froesch ER. Beneficial metabolic effects of insulin-like growth factor I in patients with severe insulin-resistant diabetes type A. Eur J Endocrinol. 1994;131:251-7.

150. Saukkonen T, Amin R, Williams RM, Fox C, Yuen KC, White MA, Umpleby AM, Acerini CL, Dunger DB. Dose-Dependent Effects of Recombinant Human Insulin-like Growth Factor (IGF)-I/IGF Binding Protein-3 Complex on Overnight Growth Hormone Secretion and Insulin Sensitivity in Type 1 Diabetes. Eur J Endocrinol. 2004;89:4634-41.

151. Carroll PV, Umpleby M, Alexander EL, Egel VA, Callison KV, Sönksen $\mathrm{PH}$, Russell-Jones DL. Recombinant human insulin-like growth factor-I (rhlGF-I) therapy in adults with type 1 diabetes mellitus: effects on IGFs, IGF-binding proteins, glucose levels and insulin treatment. Clin Endocrinol (Oxf). 1998;49:739-46.

152. Cheetham TD, Holly JM, Clayton K, Cwyfan-Hughes S, Dunger DB. The effects of repeated daily recombinant human insulin-like growth factor I administration in adolescents with type 1 diabetes. Diabet Med. 1995;12:885-92. 
153. Zenobi PD, Jaeggi-Groisman SE, Riesen WF, Røder ME, Froesch ER. Insulin-like growth factor-I improves glucose and lipid metabolism in type 2 diabetes mellitus. J Clin Invest. 1992;90:2234-41.

154. Pratipanawatr T, Pratipanawatr W, Rosen C, Berria R, Bajaj M, Cusi K, Mandarino L, Kashyap S, Belfort R, DeFronzo RA. Effect of IGF-I on FFA and glucose metabolism in control and type 2 diabetic subjects. Am J Physiol Endocrinol Metab. 2002;282:E1360-8.

155. Moses AC, Young SC, Morrow LA, O'Brien M, Clemmons DR. Recombinant human insulin-like growth factor I increases insulin sensitivity and improves glycemic control in type II diabetes. Diabetes. 1996;45:91-100

156. Federici M, Zucaro L, Porzio O, Massoud R, Borboni P, Lauro D, Sesti G. Increased expression of insulin/insulin-like growth factor-1 hybrid receptors in skeletal muscle of noninsulin-dependent diabetes mellitus subjects. J Clin Invest. 1996;98:2887-93.

157. Alexandrides T, Moses AC, Smith RJ. Developmental expression of receptors for insulin, insulin-like growth factor I (IGF-I), and IGF-II in rat skeletal muscle. Endocrinology. 1989;124:1064-76.

158. Turkalj I, Keller U, Ninnis R, Vosmeer S, Stauffacher W. Effect of increasing doses of recombinant human insulin-like growth factor-I on glucose, lipid, and leucine metabolism in man. J Clin Endocrinol Metab. 1992;75:1186-91.

159. Di Cola G, Cool MH, Accili D. Hypoglycemic effect of insulin-like growth factor-1 in mice lacking insulin receptors. J Clin Invest. 1997;99:2538-44.

160. Berryman DE, Glad CAM, List EO, Johannsson G. The GH/IGF-1 axis in obesity: pathophysiology and therapeutic considerations. Nat Rev Endocrinol. 2013;9:346-56.

161. Yakar S, Liu JL, Fernandez AM, Wu Y, Schally AV, Frystyk J, Chernausek SD, Mejia W, Le Roith D. Liver-specific igf-1 gene deletion leads to muscle insulin insensitivity. Diabetes. 2001;50:1110-8.

162. Fernández AM, Kim JK, Yakar S, Dupont J, Hernandez-Sanchez C, Castle AL, Filmore J, Shulman Gl, Le Roith D. Functional inactivation of the IGF-I and insulin receptors in skeletal muscle causes type 2 diabetes. Genes Dev. 2001;15:1926-34

163. Pennisi P, Gavrilova O, Setser-Portas J, Jou W, Santopietro S, Clemmons D, Yakar S, LeRoith D. Recombinant human insulin-like growth factor-I treatment inhibits gluconeogenesis in a transgenic mouse model of type 2 diabetes mellitus. Endocrinology. 2006;147:2619-30.

164. De Ita JR, Castilla-Cortázar I, Aguirre GA, Sánchez-Yago C, Santos-Ruiz MO, Guerra-Menéndez L, Martín-Estal I, García-Magariño M, Lara-Díaz VJ, Puche JE, Muñoz U. Altered liver expression of genes involved in lipid and glucose metabolism in mice with partial IGF-1 deficiency: an experimental approach to metabolic syndrome. J Transl Med. 2015;13:326.

165. Yuen KCJ, Dunger DB. Therapeutic aspects of growth hormone and insulin-like growth factor-I treatment on visceral fat and insulin sensitivity in adults. Diabetes Obes Metab. 2007;9:11-22.

166. del Rincon J-P, lida K, Gaylinn BD, McCurdy CE, Leitner JW, Barbour LA, Kopchick JJ, Friedman JE, Draznin B, Thorner MO. Growth hormone regulation of p85alpha expression and phosphoinositide 3-kinase activity in adipose tissue: mechanism for growth hormone-mediated insulin resistance. Diabetes. 2007;56:1638-46.

167. Barbour LA, Mizanoor Rahman S, Gurevich I, Leitner JW, Fischer SJ, Roper MD, Knotts TA, Vo Y, McCurdy CE, Yakar S, Leroith D, Kahn CR, Cantley LC, Friedman JE, Draznin B. Increased P85alpha is a potent negative regulator of skeletal muscle insulin signaling and induces in vivo insulin resistance associated with growth hormone excess. J Biol Chem. 2005;280:37489-94.

168. Frystyk J. Free insulin-like growth factors - measurements and relationships to growth hormone secretion and glucose homeostasis. Growth Hormone IGF Res. 2004;14:337-75.

169. Conover CA, Lee PD, Kanaley JA, Clarkson JT, Jensen MD. Insulin regulation of insulin-like growth factor binding protein-1 in obese and nonobese humans. J Clin Endocrinol Metab. 1992;74:1355-60.

170. Nam SY, Lee EJ, Kim KR, Cha BS, Song YD, Lim SK, Lee HC, Huh KB. Effect of obesity on total and free insulin-like growth factor (IGF)-1, and their relationship to IGF-binding protein (BP)-1, IGFBP-2, IGFBP-3, insulin, and growth hormone. Int J Obes Relat Metab Disord. 1997;21:355-9.

171. Henry RR, Abrams L, Nikoulina S, Ciaraldi TP. Insulin action and glucose metabolism in nondiabetic control and NIDDM subjects. Comparison using human skeletal muscle cell cultures. Diabetes. 1995:44:936-46.
172. Furling D, Marette A, Puymirat J. Insulin-like growth factor I circumvents defective insulin action in human myotonic dystrophy skeletal muscle cells. Endocrinology. 1999;140:4244-50.

173. Clemmons DR, Snyder DK, Busby WH. Variables controlling the secretion of insulin-like growth factor binding protein-2 in normal human subjects. J Clin Endocrinol Metab. 1991;73:727-33.

174. Wheatcroft SB, Kearney MT, Shah AM, Ezzat VA, Miell JR, Modo M, Williams SCR, Cawthorn WP, Medina-Gomez G, Vidal-Puig A, Sethi JK, Crossey PA. IGF-binding protein-2 protects against the development of obesity and insulin resistance. Diabetes. 2007;56:285-94.

175. Schedlich LJ, Le Page SL, Firth SM, Briggs LJ, Jans DA, Baxter RC. Nuclear import of Insulin-like Growth Factor-binding Protein-3 and -5 is mediated by the importin? Subunit. J Biol Chem. 2000;275:23462-70.

176. Goerner A, Reichstein M, Tomelleri E, Hanan N, Rambal S, Papale D, Dragoni D, Schmullius C. Remote sensing of ecosystem light use efficiency with MODIS-based PRI. Biogeosciences. 2011;8:189-202.

177. Silha JV, Gui Y, Murphy LJ. Impaired glucose homeostasis in insulin-like growth factor-binding protein-3-transgenic mice. Am J Physiol Endocrinol Metab. 2002;283:E937-45.

178. Modric T, Silha JV, Shi Z, Gui Y, Suwanichkul A, Durham SK, Powell DR, Murphy LJ. Phenotypic manifestations of insulin-like growth factorbinding protein-3 overexpression in transgenic mice. Endocrinology. 2001;142:1958-67.

179. López-Bermejo A, Khosravi J, Fernández-Real JM, Hwa V, Pratt KL, Casamitjana R, Garcia-Gil MM, Rosenfeld RG, Ricart W. Insulin resistance is associated with increased serum concentration of IGF-binding protein-related protein 1 (IGFBP-rP1/MAC25). Diabetes. 2006;55:2333-9.

180. Shao L, Huang Q, Luo M, Lai M. Detection of the differentially expressed gene IGF-binding protein-related protein-1 and analysis of its relationship to fasting glucose in Chinese colorectal cancer patients. Endocr Relat Cancer. 2004;11:141-8.

181. Scavo LM, Karas M, Murray M, Leroith D. Insulin-like growth factor-I stimulates both cell growth and lipogenesis during differentiation of human mesenchymal stem cells into adipocytes. J Clin Endocrinol Metab. 2004;89:3543-53.

182. DiGirolamo M, Edén S, Enberg G, Isaksson O, Lönnroth P, Hall K, Smith U. Specific binding of human growth hormone but not insulin-like growth factors by human adipocytes. FEBS Lett. 1986;205:15-9.

183. Mauras N, O'Brien KO, Welch S, Rini A, Helgeson K, Vieira NE, Yergey AL. Insulin-like growth factor I and growth hormone $(\mathrm{GH})$ treatment in GH-deficient humans: differential effects on protein, glucose, lipid, and calcium metabolism. J Clin Endocrinol Metab. 2000;85:1689-94.

184. Clemmons DR. The relative roles of growth hormone and IGF-1 in controlling insulin sensitivity. J Clin Invest. 2004;113:25-27.

185. LeRoith D, Yakar S. Mechanisms of disease: metabolic effects of growth hormone and insulin-like growth factor 1. Nat Clin Pract Endocrinol Metab. 2007;3:302-10

186. Heffernan M, Summers RJ, Thorburn A, Ogru E, Gianello R, Jiang WJ, $\mathrm{Ng}$ FM. The effects of human GH and its lipolytic fragment (AOD9604) on lipid metabolism following chronic treatment in obese mice and beta(3)-AR knock-out mice. Endocrinology. 2001;142:5182-9.

187. Lafontan M, Berlan M. Fat cell adrenergic receptors and the control of white and brown fat cell function. J Lipid Res. 1993;34:1057-91.

188. Hollenga C, Brouwer F, Zaagsma J. Relationship between lipolysis and cyclic AMP generation mediated by atypical beta-adrenoceptors in rat adipocytes. Br J Pharmacol. 1991;102:577-80.

189. Susulic VS, Frederich RC, Lawitts J, Tozzo E, Kahn BB, Harper ME, HimmsHagen J, Flier JS, Lowell BB. Targeted disruption of the beta 3-adrenergic receptor gene. J Biol Chem. 1995;270:29483-92.

190. Segerlantz M, Bramnert M, Manhem P, Laurila E, Groop LC. Inhibition of the rise in FFA by Acipimox partially prevents $\mathrm{GH}$-induced insulin resistance in GH-deficient adults. J Clin Endocrinol Metab. 2001;86:5813-8.

191. Nørrelund H, Nair KS, Nielsen S, Frystyk J, Ivarsen P, Jørgensen JOL, Christiansen JS, Møller N. The decisive role of free fatty acids for protein conservation during fasting in humans with and without growth hormone. J Clin Endocrinol Metab. 2003;88:4371-8.

192. Zick Y. Uncoupling insulin signalling by serine/threonine phosphorylation: a molecular basis for insulin resistance. Biochem Soc Trans. 2004;32:812-6.

193. Héron-Milhavet L, Haluzik M, Yakar S, Gavrilova O, Pack S, Jou WC, Ibrahimi A, Kim H, Hunt D, Yau D, Asghar Z, Joseph J, Wheeler MB, 
Abumrad NA, LeRoith D. Muscle-specific overexpression of CD36 reverses the insulin resistance and diabetes of MKR mice. Endocrinology. 2004; 145:4667-76.

194. Castilla-Cortazar I, Prieto J, Urdaneta E, Pascual M, Nunez M, Zudaire E, Garcia M, Quiroga J, Santidrian S. Impaired intestinal sugar transport in cirrhotic rats: correction by low doses of insulin-like growth factor I. Gastroenterology. 1997;113:1180-7.

195. Castilla-Cortázar I, Picardi A, Tosar A, Ainzúa J, Urdaneta E, García M, Pascual M, Quiroga J, Prieto J. Effect of insulin-like growth factor I on in vivo intestinal absorption of D-galactose in cirrhotic rats. Am J Physiol. 1999;276(1 Pt 1):G37-42.

196. Pérez R, Castilla-Cortázar I, Núñez M, Prado A, Mirpuri E, García M, González Barón S, Picardi A: IGF-I does not improve fat malabsorption in cirrhotic rats. J Physiol Biochem. 2001;57:59-60.

197. Mauras N, Martinez V, Rini A, Guevara-Aguirre J. Recombinant human insulin-like growth factor I has significant anabolic effects in adults with growth hormone receptor deficiency: studies on protein, glucose, and lipid metabolism. 2000;85:3036-42.

198. Clemmons DR. Metabolic actions of insulin-like growth factor-l in normal physiology and diabetes. Endocrinol Metab Clin North Am. 2012;41:425-43.

199. García-Fernández M, Delgado G, Puche JE, González-Barón S, Cortázar IC. Low doses of insulin-like growth factor I improve insulin resistance, lipid metabolism, and oxidative damage in aging rats. Endocrinology. 2008; 149:2433-42.

200. Zhang Y, Yuan M, Bradley KM, Dong F, Anversa P, Ren J. Insulin-like growth factor 1 alleviates high-fat diet-induced myocardial contractile dysfunction: role of insulin signaling and mitochondrial function. Hypertension. 2012;59:680-93.

201. Moxley RT, Arner P, Moss A, Skottner A, Fox M, James D, Livingston $\mathrm{JN}$. Acute effects of insulin-like growth factor I and insulin on glucose metabolism in vivo. Am J Physiol. 1990;259:E561-7.

202. Le Roith D, Kim H, Fernandez AM, Accili D. Inactivation of muscle insulin and IGF-I receptors and insulin responsiveness. Curr Opin Clin Nutr Metab Care. 2002;5:371-5.

203. Simpson H, Savine R, Sönksen P, Bengtsson B-A, Carlsson L, Christiansen JS, Clemmons D, Cohen P, Hintz R, Ho K, Mullis P, Robinson I, Strasburger C, Tanaka T, Thorner M. Growth hormone replacement therapy for adults: into the new millennium. Growth Horm IGF Res. 2002;12:1-33.

204. Jacob R, Barrett E, Plewe G, Fagin KD, Sherwin RS. Acute effects of insulin-like growth factor I on glucose and amino acid metabolism in the awake fasted rat. Comp Insulin J Clin Invest. 1989;83:1717-23.

205. Saukkonen T, Shojaee-Moradie F, Williams RM, Amin R, Yuen KC, Watts A, Acerini CL, Umpleby AM, Dunger DB. Effects of recombinant human IGF-I/IGF-binding protein-3 complex on glucose and glycerol metabolism in type 1 diabetes. Diabetes. 2006;55:2365-70.

206. Baumann MU, Schneider H, Malek A, Palta V, Surbek DV, Sager R, Zamudio S, Illsley NP. Regulation of human trophoblast GLUT1 glucose transporter by insulin-like growth factor I (IGF-I). PLoS One. 2014;9:e106037.

207. Succurro E, Andreozzi F, Marini MA, Lauro R, Hribal ML, Perticone F, Sesti G. Low plasma insulin-like growth factor-1 levels are associated with reduced insulin sensitivity and increased insulin secretion in nondiabetic subjects. Nutr Metab Cardiovasc Dis. 2009;19:713-9.

208. Sandhu MS, Heald AH, Gibson JM, Cruickshank JK, Dunger DB, Wareham NJ. Circulating concentrations of insulin-like growth factor-I and development of glucose intolerance: a prospective observational study. Lancet. 2002;359:1740-5.

209. O'Connell T, Clemmons DR. IGF-I/IGF-binding protein-3 combination improves insulin resistance by $\mathrm{GH}$-dependent and independent mechanisms. J Clin Endocrinol Metab. 2002;87:4356-60.

210. Thankamony A, Capalbo D, Marcovecchio ML, Sleigh A, Jørgensen SW, Hill NR, Mooslehner K, Yeo GSH, Bluck L, Juul A, Vaag A, Dunger DB. Low circulating levels of IGF-1 in healthy adults are associated with reduced $\beta$-cell function, increased intramyocellular lipid, and enhanced fat utilization during fasting. J Clin Endocrinol Metab. 2014;99:2198-207.

211. Bereket $\mathrm{A}$, Lang $\mathrm{CH}$, Blethen SL, Gelato MC, Fan J, Frost RA, Wilson TA Effect of insulin on the insulin-like growth factor system in children with new-onset insulin-dependent diabetes mellitus. 1995;80:1312-7.

212. Leroith D. Pathophysiology of the metabolic syndrome: implications for the cardiometabolic risks associated with type 2 diabetes. Am J Med Sci. 2012;343:13-6.
213. Saydah S, Ballard-Barbash R, Potischman N. Association of metabolic syndrome with insulin-like growth factors among adults in the US. Cancer Causes Control. 2009;20:1309-16.

214. Mannino GC, Greco A, De Lorenzo C, Andreozzi F, Marini MA, Perticone F, Sesti G. A fasting insulin-raising allele at IGF1 locus is associated with circulating levels of IGF-1 and insulin sensitivity. PLoS One. 2013;8.

215. Efstratiadis G, Tsiaousis G, Athyros VG, Karagianni D, Pavlitou-Tsiontsi A, Giannakou-Darda A, Manes C. Total serum insulin-like growth factor-1 and C-reactive protein in metabolic syndrome with or without diabetes. Angiology. 2006;57:303-11.

216. Savastano S, Di C, Barrea L, Colao A. The complex relationship between obesity and the somatropic axis : the long and winding road. YGHIR. 2014;24:221-6.

217. Sierra-Johnson J, Romero-Corral A, Somers VK, Lopez-Jimenez F, Mälarstig A, Brismar K, Hamsten A, Fisher RM, Hellénius M-L. IGF-I/ IGFBP-3 ratio: a mechanistic insight into the metabolic syndrome. Clin Sci (Lond). 2009;116:507-12.

218. Rietveld I, Janssen JAMJL, Van Rossum EFC, Houwing-Duistermaat JJ, Rivadeneira F, Hofman A, Pols HAP, Van Duijn CM, Lamberts SWJ. A polymorphic CA in the IGF-I gene is associated with gender-specific differences in body height, but has no effect on the secular trend in body height. Clin Endocrinol (Oxf). 2004;61:195-203.

219. Vaessen $N$, Heutink $P$, Janssen JA, Witteman JCM, Testers $L$, Hofman $A$, Lamberts SWJ, Oostra BA, Pols HAP, Van Duijn CM. A polymorphism in the gene for IGF-I: functional properties and risk for type 2 diabetes and myocardial infarction. Diabetes. 2001;50:637-42.

220. Heald AH, Sharma R, Anderson SG, Vyas A, Siddals K, Patel J, Bhatnagar D, Prabharkaran D, Rudenski A, Hughes E, Durrington P, Gibson JM, Cruickshank JK. Dietary intake and the insulin-like growth factor system: effects of migration in two related populations in India and Britain with markedly different dietary intake. Public Health Nutr. 2005;8:620-7.

221. Lam CSP, Chen MH, Lacey SM, Yang Q, Sullivan LM, Xanthakis V, Safa R, Smith HM, Peng $X$, Sawyer DB, Vasan RS. Circulating insulin-like growth factor-1 and its binding protein-3: metabolic and genetic correlates in the community. Arterioscler Thromb Vasc Biol. 2010;30:1479-84.

222. Colao A. The GH-IGF-I axis and the cardiovascular system: Clinical implications. Clin. Endocr. 2008;69:347-58.

223. Akanji AO, Smith RJ. The Insulin-Like growth factor system, metabolic syndrome, and cardiovascular disease risk. Metab Syndr Relat Disor. 2012;10:3-13.

224. Dunger D, Yuen K, Ong K. Insulin-like growth factor I and impaired glucose tolerance. Horm Res. 2004;62:101-7.

225. Martha S, Pantam N, Thungathurthi S, Rao VLN, Devarakonda K. Study of insulin resistance in relation to serum IGF-I levels in subjects with different degrees of glucose tolerance. Int J Diabetes Dev Ctries. 2008;28:54-9.

226. Sesti G, Sciacqua A, Cardellini M, Marini MA, Maio R, Vatrano M, Succurro E, Lauro R, Federici M, Perticone F. Plasma concentration of IGF-I is independently associated with insulin sensitivity in subjects with different degrees of glucose tolerance. Diabetes Care. 2005;28:120-5

227. Salmon AB, Lerner C, Ikeno Y, Motch Perrine SM, McCarter R, Sell C. Altered metabolism and resistance to obesity in long-lived mice producing reduced levels of IGF-1. Am J Physiol Endocrinol Metab. 2015;308. doi:10.1152/ajpendo.00558.2014.

228. Baker J, Liu JP, Robertson EJ, Efstratiadis A. Role of insulin-like growth factors in embryonic and postnatal growth. Cell. 1993;75:73-82.

229. Yakar S, Setser J, Zhao H, Stannard B, Haluzik M, Glatt V, Bouxsein ML, Kopchick JJ, LeRoith D. Inhibition of growth hormone action improves insulin sensitivity in liver IGF-1-deficient mice. J Clin Invest. 2004;113:96-105.

230. Paruthi J, Gill N, Mantzoros CS: Adipokines in the HIV/HAART-associated lipodystrophy syndrome. Metabolism: Clinical and Experimental 2013:1199-1205.

231. Teppala S, Shankar A. Association between serum IGF-1 and diabetes among US adults. Diabetes Care. 2010;33:2257-9.

232. Scott RA, Lagou V, Welch RP, Wheeler E, Montasser ME, Luan J, Mägi R, Strawbridge RJ, Rehnberg E, Gustafsson S, Kanoni S, Rasmussen-Torvik L, Yengo L, Lecoeur C, Shungin D, Sanna S, Sidore C, Johnson PCD, Jukema JW, Johnson T, Mahajan A, Verweij N, Thorleifsson G, Hottenga J-J, Shah S, Smith AV, Sennblad B, Gieger C, Salo P, Perola M, et al. Largescale association analyses identify new loci influencing glycemic traits 
and provide insight into the underlying biological pathways. Nat Genet. 2012;44:991-1005

233. Oh J, Kim JY, Park S, Youn JC, Son NH, Shin DJ, Lee SH, Kang SM, Jee $\mathrm{SH}$, Jang $\mathrm{Y}$. The relationship between insulin-like growth factor-1 and metabolic syndrome, independent of adiponectin. Clin Chim Acta. 2012;413:506-10

234. Mallea-Gil MS, Ballarino MC, Spiraquis A, Iriarte M, Kura M, Gimenez S, Oneto A, Guitelman M, Machado R, Miguel CM. IGF-1 levels in different stages of liver steatosis and its association with metabolic syndrome. Acta Gastroenterol Latinoam. 2012;42:20-6.

235. Sandhu MS. Insulin-like growth factor-I and risk of type 2 diabetes and coronary heart disease: molecular epidemiology. Endocr Dev. 2005;9:44-54.

236. LeRoith D, Gavrilova O. Mouse models created to study the pathophysiology of Type 2 diabetes. Int J Biochem Cell Biol. 2006;38:904-12.

237. Bokov AF, Garg N, Ikeno Y, Thakur S, Musi N, DeFronzo RA, Zhang N, Erickson RC, Gelfond J, Hubbard GB, Adamo ML, Richardson A. Does reduced IGF-1R signaling in igf1 $\mathrm{r} \pm$ mice alter aging? PLoS One. 2011;6.

238. Jensen RBB, Chellakooty M, Vielwerth S, Vaag A, Larsen T, Greisen G, Skakkebæk NE, Scheike T, Juul A. Intrauterine growth retardation and consequences for endocrine and cardiovascular diseases in adult life: Does insulin-like growth factor-I play a role? Horm Res. 2003;60(suppl 3):136-48.

239. Yaghootkar H, Freathy RM. Genetic origins of low birth weight. Curr Opin Clin Nutr Metab Care. 2012:258-64.

240. Kreitschmann-Andermahr I, Suarez P, Jennings R, Evers N, Brabant G. $\mathrm{GH} / \mathrm{IGF}-\mathrm{I}$ regulation in obesity - mechanisms and practical consequences in children and adults. Horm Res Paediatrics. 2010:153-60.

241. Sabin MA, Russo VC, Azar WJ, Yau SW, Kiess W, Werther GA. IGFBP-2 at the interface of growth and metabolism-implications for childhood obesity. Pediatr Endocrinol Rev. 2011;8:382-93.

242. Rasmussen MH, Frystyk J, Andersen T, Breum L, Christiansen JS, Hilsted J. The impact of obesity, fat distribution, and energy restriction on insulin-like growth factor-1 (IGF-1), IGF-binding protein-3, insulin, and growth hormone. Metabolism. 1994:43:315-9.

243. De Pergola G, Zamboni M, Pannacciulli N, Turcato E, Giorgino F, Armellini F, Logoluso F, Sciaraffia M, Bosello O, Giorgino R. Divergent effects of short-term, very-low-calorie diet on insulin-like growth factor-I and insulin-like growth factor binding protein-3 serum concentrations in premenopausal women with obesity. Obes Res. 1998;6:408-15.

244. Kunitomi M, Wada J, Takahashi K, Tsuchiyama Y, Mimura Y, Hida K, Miyatake N, Fujii M, Kira S, Shikata K, Maknio H. Relationship between reduced serum IGF-I levels and accumulation of visceral fat in Japanese men. Int J Obes Relat Metab Disord. 2002;26:361-9.

245. Mårin P, Kvist H, Lindstedt G, Sjöström L, Björntorp P. Low concentrations of insulin-like growth factor-I in abdominal obesity. Int J Obes Relat Metab Disord. 1993;17:83-9.

246. Rasmussen MH, Hvidberg A, Juul A, Main KM, Gotfredsen A, Skakkebae $\mathrm{NE}$, Hilsted J. Massive weight loss restores 24-hour growth hormone release profiles and serum insulin-like growth factor-l levels in obese subjects. J Clin Endocrinol Metab. 1995;80:1407-15.

247. Lang CH, Nystrom GJ, Frost RA. Regulation of IGF binding protein-1 in hep $\mathrm{G} 2$ cells by cytokines and reactive oxygen species. Am J Physiol. 1999;276(3 Pt 1):G719-27.

248. Fan J, Char D, Bagby GJ, Gelato MC, Lang CH. Regulation of insulin-like growth factor-I (IGF-I) and IGF-binding proteins by tumor necrosis factor. Am J Physiol. 1995;269(5 Pt 2):R1204-12.

249. Samstein B, Hoimes ML, Fan J, Frost RA, Gelato MC, Lang CH. IL-6 stimulation of insulin-like growth factor binding protein (IGFBP)-1 production. Biochem Biophys Res Commun. 1996;228:611-5.

250. Agladıoglu SY, Cetınkaya S, Savas Erdeve S, Onder A, Kendırcı HNP, Bas VN, Aycan Z. Diabetes mellitus with Laron syndrome: case report. J Pediatr Endocrinol Metab. 2013;26:955-8.

251. Laron Z, Weinberger D. Diabetic retinopathy in two patients with congenital IGF-I deficiency (Laron syndrome). Eur J Endocrinol. 2004;151:103-6.

252. Heald AH, Anderson SG, Ivison F, Laing I, Gibson JM, Cruickshank K. C-reactive protein and the insulin-like growth factor (IGF)-system in relation to risk of cardiovascular disease in different ethnic groups. Atherosclerosis. 2003;170:79-86.
253. Petersson U, Östgren CJ, Brudin L, Brismar K, Nilsson PM. Low levels of insulin-like growth-factor-binding protein-1 (IGFBP-1) are prospectively associated with the incidence of type 2 diabetes and impaired glucose tolerance (IGT): the Söderåkra Cardiovascular Risk Factor Study. Diabetes Metab. 2009;35:198-205.

254. Lewitt MS, Denyer GS, Cooney GJ, Baxter RC. Insulin-like growth factorbinding protein-1 modulates blood glucose levels. Endocrinology. 1991;129:2254-6.

255. Frystyk J, Skjaerbaek C, Vestbo E, Fisker S, Orskov H. Circulating levels of free insulin-like growth factors in obese subjects: the impact of type 2 diabetes. Diabetes Metab Res Rev. 1999;15:314-22.

256. Lewitt MS, Hilding A, Brismar K, Efendic S, Östenson CG, Hall K. IGFbinding protein 1 and abdominal obesity in the development of type 2 diabetes in women. Eur J Endocrinol. 2010;163:233-42.

257. Cheetham TD, Holly JMP, Baxter RC, Meadows K, Jones J, Taylor AM, Dunger DB. The effects of recombinant human IGF-I administration on concentrations of acid labile subunit, IGF binding protein-3, IGF-I, IGF-ii and proteolysis of IGF binding protein-3 in adolescents with insulindependent diabetes mellitus. J Endocrinol. 1998;157:81-7.

258. Bang P, Brismar K, Rosenfeld RG. Increased proteolysis of insulin-like growth factor-binding protein-3 (IGFBP-3) in Noninsulin-dependent diabetes mellitus serum, with elevation of a 29-kilodalton $(\mathrm{kDa})$ glycosylated IGFBP-3 fragment contained in the approximately 130- To 150-kDa Ternary C. J Clin Endocrinol Metab. 1994;78:1119-27.

259. Sakai K, D’Ercole AJ, Murphy $L$, Clemmons DR. Physiological differences in insulin-like growth factor binding protein-1 (IGFBP-1) phosphorylation in IGFBP-1 transgenic mice. Diabetes. 2001;50:32-8.

260. Reinehr T, Kleber M, Toschke AM, Woelfle J, Roth CL. Longitudinal association between IGFBP-1 levels and parameters of the metabolic syndrome in obese children before and after weight loss. Int J Pediatr Obes. 2011;6:236-43.

261. Wabitsch M, Blum WF, Muche R, Heinze E, Haug C, Mayer H, Teller W. Insulin-like growth factors and their binding proteins before and after weight loss and their associations with hormonal and metabolic parameters in obese adolescent girls. Int J Obes Relat Metab Disord. 1996;20:1073-80.

262. Heald AH, Kaushal K, Siddals KW, Rudenski AS, Anderson SG, Gibson JM. Insulin-like growth factor binding protein-2 (IGFBP-2) is a marker for the metabolic syndrome. Exp Clin Endocrinol Diabetes. 2006;114:371-6.

263. Gehrig SM, van der Poel C, Hoeflich A, Naim T, Lynch GS, Metzger F. Therapeutic potential of PEGylated insulin-like growth factor I for skeletal muscle disease evaluated in two murine models of muscular dystrophy. Growth Horm IGF Res. 2012;22:69-75.

264. Backeljauw PF, Underwood LE. GHIS Collaborative Group. Growth hormone insensitivity syndrome: therapy for 6.5-7.5 years with recombinant insulin-like growth factor I in children with growth hormone insensitivity syndrome: a clinical research center study. J Clin Endocrinol Metab. 2001;86:1504-10.

265. Laron Z, Lilos P, Klinger B. Growth curves for Laron syndrome. Arch Dis Child. 1993;68:768-70

266. Savage MO, Camacho-Hübner C, Dunger DB. Therapeutic applications of the insulin-like growth factors. Growth Horm IGF Res. 2004;14:301-8.

267. Azcona C, Preece MA, Rose SJ, Fraser N, Rappaport R, Ranke MB, Savage MO. Growth response to rhIGF-I 80 microg/kg twice daily in children with growth hormone insensitivity syndrome: relationship to severity of clinical phenotype. Clin Endocrinol (Oxf). 1999;51:787-92.

268. Ranke MB, Savage MO, Chatelain PG, Preece MA, Rosenfeld RG, Wilton P. Long-term treatment of growth hormone insensitivity syndrome with IGF-l. Results of the European Multicentre Study. The Working Group on Growth Hormone Insensitivity Syndromes. Horm Res. 1999;51:128-34.

269. Herndon DN, Ramzy PI, DebRoy MA, Zheng M, Ferrando AA, Chinkes DL, Barret JP, Wolfe RR, Wolf SE. Muscle protein catabolism after severe burn: effects of IGF-1/IGFBP-3 treatment. Ann Surg. 1999;229:713-20 (discussion 720-2).

270. Jeschke MG, Barrow RE, Herndon DN. Insulinlike growth factor I plus insulinlike growth factor binding protein 3 attenuates the proinflammatory acute phase response in severely burned children. Ann Surg. 2000;231:246-52

271. Jeschke MG, Herndon DN, Vita R, Traber DL, Jauch KW, Barrow RE. IGF-I/ BP-3 administration preserves hepatic homeostasis after thermal injury 
which is associated with increases in no and hepatic NF-kappa B. Shock. 2001;16:373-9.

272. Spies M, Wolf SE, Barrow RE, Jeschke MG, Herndon DN. Modulation of types I and II acute phase reactants with insulin-like growth factor-1/ binding protein-3 complex in severely burned children. Crit Care Med. 2002;30:83-8.

273. Debroy MA, Wolf SE, Zhang XJ, Chinkes DL, Ferrando AA, Wolfe RR, Herndon DN. Anabolic effects of insulin-like growth factor in combination with insulin-like growth factor binding protein-3 in severely burned adults. J Trauma. 1999;47:904-10 (discussion 910-1).

274. Grinspoon S, Thomas L, Miller K, Herzog D, Klibanski A. Effects of recombinant human IGF-I and oral contraceptive administration on bone density in anorexia nervosa. J Clin Endocrinol Metab. 2002;87:2883-91

275. Boonen S, Rosen C, Bouillon R, Sommer A, McKay M, Rosen D, Adams S, Broos P, Lenaerts J, Raus J, Vanderschueren D, Geusens P. Musculoskeletal effects of the recombinant human IGF-I/IGF binding protein-3 complex in osteoporotic patients with proximal femoral fracture: a double-blind, placebo-controlled pilot study. J Clin Endocrinol Metab. 2002;87:1593-9.

276. Clemmons DR, Moses AC, Sommer A, Jacobson W, Rogol AD, Sleevi MR, Allan G. Rh/IGF-1/rhlGFBP-3 administration to patients with type 2 diabetes mellitus reduces insulin requirements while also lowering fasting glucose. Growth Horm IGF Res. 2005;15:265-74.

277. Clemmons DR, Moses AC, McKay MJ, Sommer A, Rosen DM, Ruckle J. The combination of insulin-like growth factor I and insulin-like growth factor-binding protein-3 reduces insulin requirements in insulindependent type 1 diabetes: evidence for in vivo biological activity. J Clin Endocrinol Metab. 2000;85:1518-24.

278. Norby FL, Aberle NS, Kajstura J, Anversa P, Ren J. Transgenic overexpression of insulin-like growth factor I prevents streptozotocin-induced cardiac contractile dysfunction and ??-adrenergic response in ventricular myocytes. J Endocrinol. 2004;180:175-82.

279. Norby FL, Wold LE, Duan J, Hintz KK, Ren J. IGF-I attenuates diabetesinduced cardiac contractile dysfunction in ventricular myocytes. Am J Physiol Endocrinol Metab. 2002;283:E658-66.

280. Lee EK, Gorospe M: Minireview: Posttranscriptional regulation of the insulin and insulin-like growth factor systems. Endocrinology. 2010;151:1403-8
281. Rosenbloom AL. Mecasermin (recombinant human insulin-like growth factor I). Adv Ther. 2009;26:40-54.

282. Pekic S, Popovic V. GH therapy and cancer risk in hypopituitarism: What we know from human studies. Eur J Endocrinol. 2013.

283. Ebeling PR, Jones JD, O'Fallon WM, Janes CH, Riggs BL. Short-term effects of recombinant human insulin-like growth factor I on bone turnover in normal women. J Clin Endocrinol Metab. 1993;77:1384-7.

284. Bright GM, Mendoza JR, Rosenfeld RG. Recombinant human insulin-like growth factor-1 treatment: ready for primetime. Endocrinol Metabol Clin N Am. 2009;38:625-38.

285. Quattrin T, Thrailkill K, Baker L, Litton J, Dwigun K, Rearson M, Poppenheimer M, Giltinan D, Gesundheit N, Martha P. Dual hormonal replacement with insulin and recombinant human insulin-like growth factor I in IDDM. Effects on glycemic control, IGF-I levels, and safety profile. Diabetes Care. 1997;20:374-80.

286. Guevara-Aguirre J, Vasconez O, Martinez V, Martinez AL, Rosenbloom AL, Diamond FB, Gargosky SE, Nonoshita L, Rosenfeld RG. A randomized, double blind, placebo-controlled trial on safety and efficacy of recombinant human insulin-like growth factor-l in children with growth hormone receptor deficiency. J Clin Endocrinol Metab. 1995;80:1393-8.

287. Berg U, Bang P. Exercise and circulating insulin-like growth factor I. Horm Res. 2004;62(suppl 1):50-8.

288. Brahm H, Piehl-Aulin K, Saltin B, Ljunghall S. Net fluxes over working thigh of hormones, growth factors and biomarkers of bone metabolism during short lasting dynamic exercise. Calcif Tissue Int. 1997;60:175-80.

289. Carro E, Trejo JL, Busiguina S, Torres-Aleman I. Circulating insulin-like growth factor I mediates the protective effects of physical exercise against brain insults of different etiology and anatomy. J Neurosci. 2001;21:5678-84.

290. Anderson MF, Aberg MAI, Nilsson M, Eriksson PS. Insulin-like growth factor-l and neurogenesis in the adult mammalian brain. Brain Res Dev Brain Res. 2002;134:115-22.

291. Huffman DM, Farias Quipildor G, Mao K, Zhang X, Wan J, Apontes P, Cohen P, Barzilai N. Central insulin-like growth factor-1 (IGF-1) restores whole-body insulin action in a model of age-related insulin resistance and IGF-1 decline. Aging Cell. 2015

292. Castilla-Cortázar I, Aliaga-Montilla MA, Salvador J, García M, Delgado G, González-Barón S, Quiroga J, Prieto J. Insulin-like growth factor-l restores the reduced somatostatinergic tone controlling growth hormone secretion in cirrhotic rats. Liver. 2001:21:405-9.

\section{Submit your next manuscript to BioMed Central and we will help you at every step:}

- We accept pre-submission inquiries

- Our selector tool helps you to find the most relevant journal

- We provide round the clock customer support

- Convenient online submission

- Thorough peer review

- Inclusion in PubMed and all major indexing services

- Maximum visibility for your research

Submit your manuscript at www.biomedcentral.com/submit

\section{() Biomed Central}

